\title{
Pennsylvanian (mid-Bolsovian to Asturian) megaspores and large pollen of the Bristol Coalfield, UK
}

\author{
JANINE L. PENDLETON* \& CHARLES H. WELLMAN \\ Department of Animal and Plant Sciences, University of Sheffield, Alfred Denny Building, Western Bank, Sheffield S10 2TN, UK \\ *Corresponding author (e-mail: janine.pendleton@petrostrat.com)
}

\begin{abstract}
A detailed account of assemblages of megaspores and large pollen grains from the midBolsovian to late Asturian Warwickshire Group (Winterbourne, Pennant Sandstone and Grovesend formations) of the Bristol Coalfield is presented. The megaspore assemblages show certain similarities to those from the well-documented, and partly coeval, sequence in the nearby Forest of Dean Coalfield. However, the Bristol Coalfield megaspore assemblages are generally less diverse. We consider the palaeoecological implications of the megaspore assemblages and conclude that differing depositional settings had different vegetational successions (including differences in the composition and diversity of megaspore-producing plants). A consideration of megaspore biostratigraphy suggests that the uppermost Pennant Sandstone Formation may be of early Asturian age, suggesting that the postulated gap between the Pennant Sandstone Formation and overlying Grovesend Formation is smaller than previously suggested. We also report the first European occurrence of the large enigmatic pteridosperm pollen grain Parasporites maccabei Schopf, 1938. J. Micropalaeontol. 32(1): 87-106, January 2013.
\end{abstract}

KEYWORDS: Carboniferous, Pennsylvanian, megaspores, pollen grains, lycopsids, pteridosperms, palaeoecology

\section{INTRODUCTION}

The Coal Measures Supergroup of the Bristol Coalfield has been little studied in comparison to other British Coalfields, such as the nearby Forest of Dean Coalfield (e.g. Arber, 1912; Spinner, 1965; Cleal, 1991) and South Wales Coalfield (e.g. Dix, 1934; Dimitrova et al., 2005; Cleal, 2007). As part of a multidisciplinary investigation of this neglected coalfield, part of the sequence (the Warwickshire Group) has been re-evaluated in terms of its stratigraphy/sedimentology, palaeobotany and palynology, and this new information utilized in a reinterpretation of its palaeoenvironments and palaeoecology. This paper is the latest contribution to a series of papers reporting on a detailed analysis of the megafloral assemblages (Pendleton et al., 2012), including permineralized material (Falcon-Lang et al., 2011; 2012), and palynology (Pendleton, personal data). This paper focuses on a series of assemblages of megaspores and large pollen grains recovered from numerous horizons spread throughout the Warwickshire Group that range from midBolsovian to late Asturian (Moscovian) in age. These assemblages have interesting palaeoecological implications, particularly when specific comparisons are made with previous detailed studies on the nearby Forest of Dean Coalfield (Spinner, 1965).

\section{MEGASPORES AND LARGE POLLEN GRAINS: A PALAEOBOTANICAL PERSPECTIVE}

Megaspores are common in the Carboniferous Coal Measures where they are found in situ (e.g. Chaloner, 1953a, b, c; 1956) and dispersed (e.g. Spinner, 1965). They derive from heterosporous plants that, at this time, included certain lycopsids, sphenopsids and possibly also ferns and progymnosperms (Bateman \& DiMichele, 1994). However, the vast majority of megaspores from the Carboniferous Coal Measures derive from lycopsids. This morphologically varied group ranged from herbaceous forms to the $40 \mathrm{~m}$ tall arborescent forms (Lepidocarpaceae and Sigillariaceae) that dominated the tropical coal measure swamps for much of their existence.
Carboniferous Coal Measures megaspore preparations occasionally also contain large pollen grains and large seeds that derive from pteridosperms. Three main groups of pteridosperm are common in the Carboniferous Coal Measures: the hydrasperman, medullosan and callistophytalean pteridosperms. In situ pollen is known from all of these groups and their pollen wall ultrastructure is also well understood through detailed transmission electron microscopy (TEM) analyses (summarized in Osborn \& Taylor, 1994; Wellman, 2009).

The hydrosperman pteridosperms were a group of relatively small plants that included shrubs and scrambling and climbing plants. In situ pollen reported from hydrasperman seed-ferns is usually small and simple pollen that is accommodated in such dispersed spore genera as Cyclogranisporites and Punctatisporites (Balme, 1995). The pollen is generally small $(40-70 \mu \mathrm{m})$, spherical, monolete or trilete, with an ornamented exospore. Wall ultrastructure has been examined in a number of investigations (Millay et al., 1978; Stidd, 1978; Taylor, 1982; Meyer-Berthaud \& Galtier, 1986). Hydrosperman pollen does not feature in megaspore preparations as it is too small.

The medullosan pteridosperms were a diverse group that developed a variety of growth habits, dominated by trees and shrubs, but also including scrambling plants and lianas. They bore foliage referred to various genera, including Neuropteris, Linopteris, Macroneuropteris, Alethopteris and Odontopteris. Pollen organs are referred to several genera, including Potoniea and Parasporotheca. The pollen is more complicated than that seen in the hydrasperman pteridosperms. Essentially it falls into two categories: those with Zonalosporites (Monoletes)-type pollen and those with Parasporites-type pollen (Balme, 1995). Zonalosporites is a simple monolete pollen grain with a bilayered exine consisting of an inner, laminate, endexine and an outer, alveolate, ectexine (e.g. Taylor, 1982). Parasporites is a bi-pseudosaccate monolete pollen grain with a bilayered exine consisting of an inner laminated endexine and an outer alveolate ectexine (Millay 


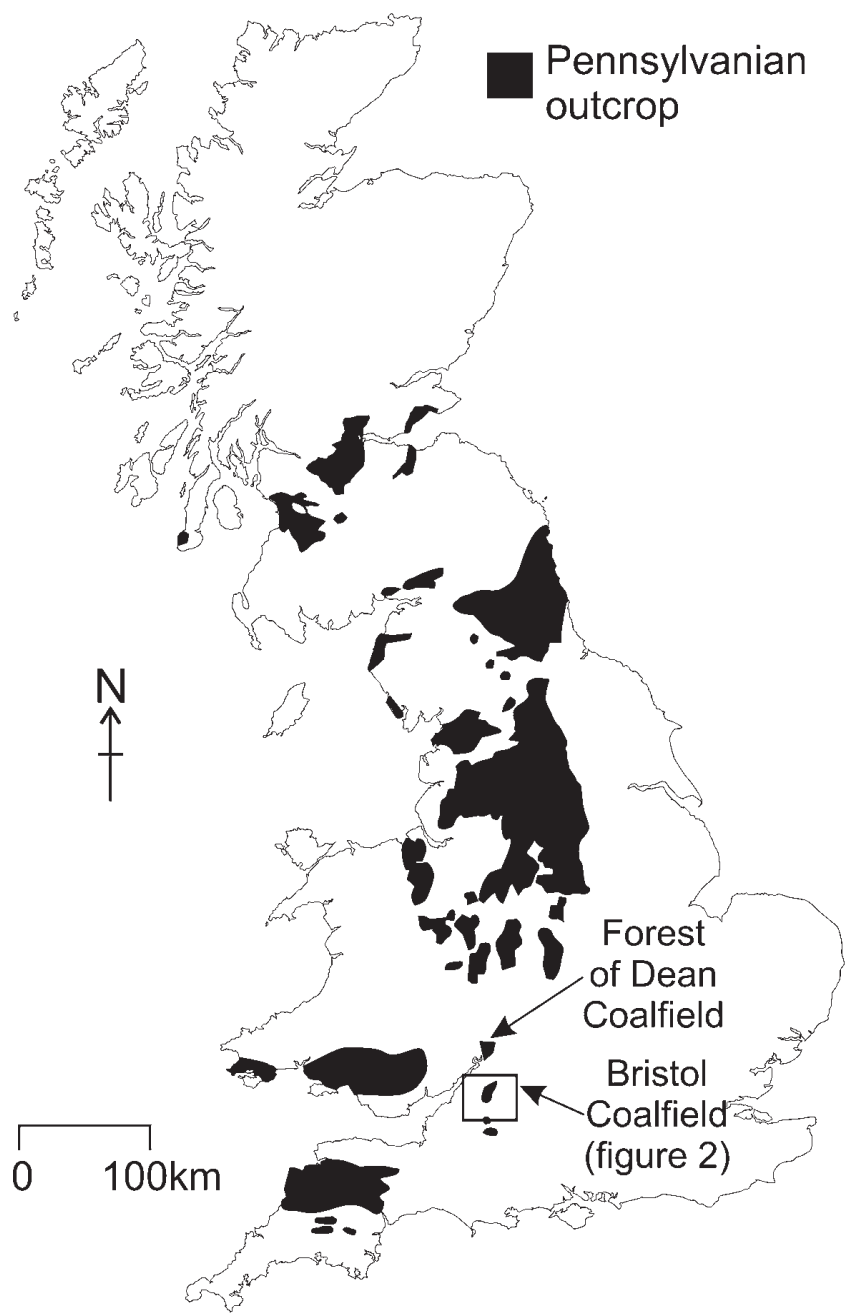

Fig. 1. Pennsylvanian outcrop in the British Isles highlighting the location of the Bristol Coalfield (box).

et al., 1978; Taylor, 1982). There is considerable size variation $(100-600 \mu \mathrm{m})$ in the pollen of this group, with some very large forms. Consequently, medullosan pollen regularly occurs in megaspore preparations.

The callistophytalean pteridosperms were a group of scrambling plants. The pollen is monosaccate and can be accommodated in the dispersed pollen taxon Vesicaspora (Balme, 1995). They are demonstrably pollen grains in that Rothwell (1972) recovered grains with emerging pollen tubes trapped within seeds. Ultrastructure of these pollen grains has been reported by Millay \& Taylor $(1974 ; 1976)$. Callistophytalean pollen is generally too small to feature in megaspore preparations.

\section{GEOLOGICAL SETTING}

Using the revised lithostratigraphic-based framework of Waters et al. $(2009 ; 2011)$, the Upper Coal Measures are now referred to as the Warwickshire Group. The Warwickshire Group of the Bristol Coalfield comprises from base to top: the Winterbourne, Pennant Sandstone and Grovesend formations. The broadly comparable lithological succession from the Forest of Dean comprises from base to top: the Trenchard, Pennant Sandstone and
Grovesend formations. The base of the Warwickshire Group is defined at the Cambriense Marine Band; locally known as the Winterbourne Marine Band in Bristol and Upper Cwmgorse Marine Band in South Wales. Where this marine band has not been proved, the first thick $(>3 \mathrm{~m})$ sandstone of Pennant-type (lithic arenite) is taken as the lower boundary of the Warwickshire Group.

\section{Palaeogeography and stratigraphy}

The Coal Measures Supergroup of the Bristol Coalfield lies to the east and NE of Bristol in the SW of Britain (Fig. 1) where it forms a north-south-orientated rhombic-shaped outcrop of $\sim 90 \mathrm{~km}^{2}$. The Warwickshire Group consists of two distinct outcrops: the Coalpit Heath Syncline in the north is separated from the southern outcrop by a wedge of South Wales Coal Measures Group in the core of the east-west-trending Kingswood Anticline (Fig. 2). For a more detailed review of the stratigraphy of the Bristol Coalfield see Pendleton et al. (2012).

The $120-180 \mathrm{~m}$ thick argillaceous measures with subordinate coals of the Winterbourne Formation lie between the Winterbourne Marine Band and the base of the Pennant Sandstone. The red measures within the upper portion of the Winterbourne Formation are postulated to reflect enhanced drainage associated with uplift along the Usk Antcline and Lower Severn Axis, which may have also provided a source for the conglomeratic bands (Waters \& Davies, 2006; Waters et al., 2009). The Winterbourne Marine Band has not been recognized in the southern limb of the Kingswood Anticline and, consequently, this member is not recognized in the southern portion of the coalfield. Kellaway \& Welch (1993) state that the marine band lies somewhere between the New Smith's and Parrot coals. Falcon-Lang et al. (2011) interpreted the Winterbourne Formation as a poorly drained coastal plain, overlain by a periodically well-drained alluvial plain which was subjected to a seasonal (subhumid) climate. Tectonic-driven water-table fluctuations have been recorded in coal measures across Britain and NW Europe at this time; which almost certainly contributed to red-bed formation in Bristol (Besly \& Turner, 1983; Besly \& Fielding, 1989; Glover et al., 1993; Pagnier \& van der Tongeren, 1996; Pierce et al., 2005; Bertier et al., 2008).

The Pennant Sandstone Formation lies stratigraphically above the Winterbourne Formation and consists of $\sim 600-1000 \mathrm{~m}$ of thick lithic arenite beds with subordinate mudstones, coals and conglomeratic horizons. The basal Downend Member reaches its maximum thickness of $\sim 600 \mathrm{~m}$ in the south, and diminishes gradually towards the north and NE, where it reaches $\sim 150 \mathrm{~m}$. The top of this member is taken at the lowermost part of the Mangotsfield coals in the Coalpit Heath Basin and the Salridge Coal in the southern limb of the Kingswood Anticline (see Pendleton et al., 2012 for discussion of the correlation between the basinal components). Conglomerate beds at the base of the Downend Member generally diminish towards the SSW, along with average clast size, suggesting a source region to the NNE (Pringle, 1921). The $\sim 600 \mathrm{~m}$ Mangotsfield Member, which lies above the Downend Member, features a distinct reduction in mudstone horizons and a lack of economically exploitable coal seams. Palaeocurrent indicators for the Mangotsfield Member suggest a source region to the south or SE (Cleal \& Thomas, 1996; Pendleton, field observations). The Pennant Sandstone Formation is interpreted as representing channels and floodplains within a broad braided-alluvial 


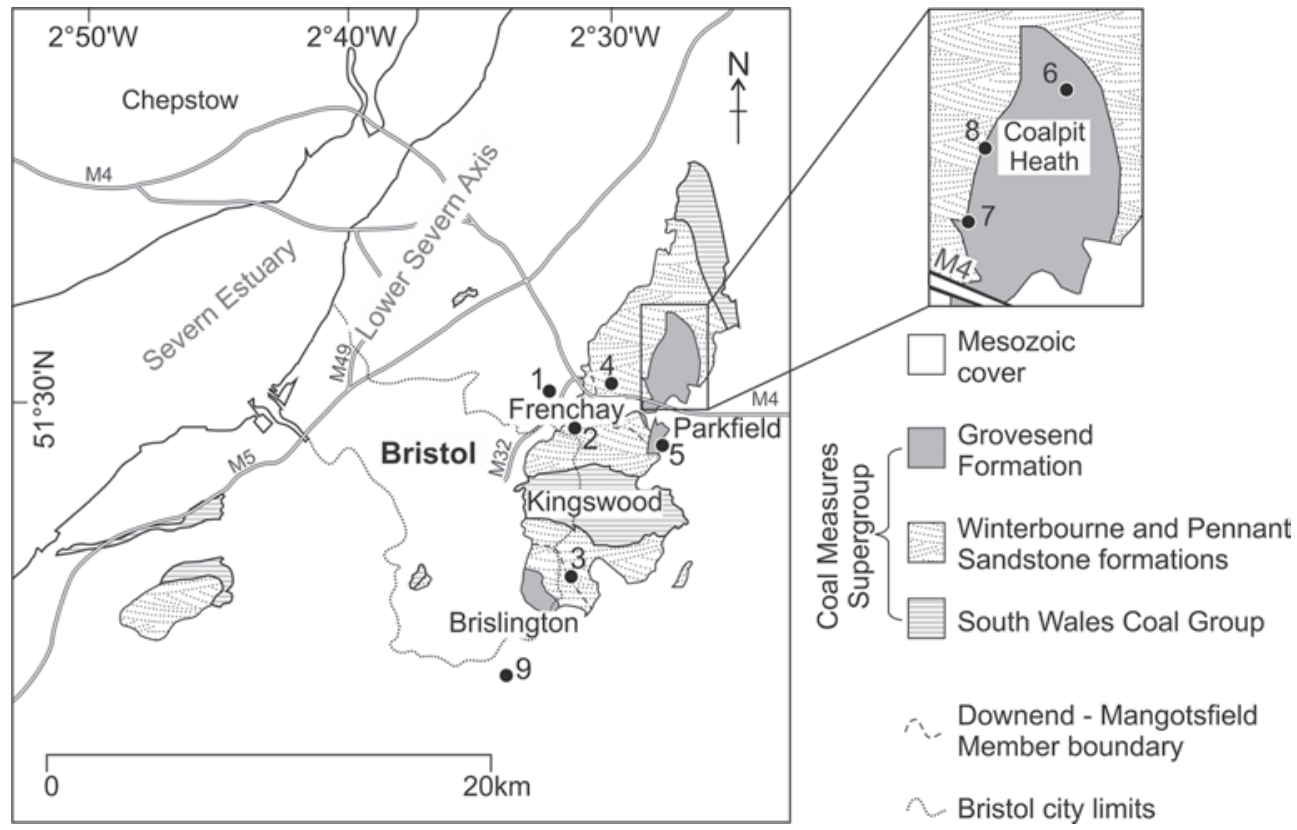

Fig. 2. Geological map of the Bristol Coalfield, highlighting productive megaspore localities. 1, Harry Stoke B borehole; 2, Grove Cottage; 3 , Salridge seam; 4, 65 The Dingle; 5, Farrington coals of Parkfield Colliery at Shortwood; 6, Coalpit Heath Colliery; 7, High seam in Serridge Adit; 8, High seam in basement of the Old Vicarage; 9, Hursley Hill borehole.

tract, sourced from the Variscan uplands to the south (Cleal \& Thomas, 1996; Waters et al., 2009).

The first pulses of Variscan-related uplift are thought to have occurred in the Bolsovian. This probably heralded a switch in sediment type and palaeocurrent direction associated with the arrival of the diachronous Pennant Sandstone Formation from the south of the basin, along with the northerly attenuation of the Downend Member.

The Grovesend Formation is the uppermost unit of the Warwickshire Group. In the Bristol Coalfield the $<70 \mathrm{~m}$ Farrington Member is an argillaceous sequence with several economically important coal seams. Four coal seams occur at Parkfield Colliery: the Great, Hollybush, Top and Hard coals. Three coal seams occur in Coalpit Heath Colliery: the High (representing merging of the Great and Hollybush coals at Parkfield Colliery), Hollybush and Hard coals. This northern merging of the coal seams suggests that subsidence rates were higher in the south. Up to $200 \mathrm{~m}$ of red mottled mudstones lay at the top of the local sequence, representing the Barren Red Member. This unit is interpreted as representing deposition of overbank lacustrine deposits on fluvial floodplains, with periods of increased drainage producing red measures (Waters et al., 2009). The Hursley Hill borehole was drilled just beyond the southern limit of the Bristol Coalfield outcrop (Fig. 2, locality 9), and penetrated the uppermost $\sim 600 \mathrm{~m}$ of the Grovesend Formation; the Radstock and Publow members.

The Forest of Dean Coalfield lies approximately $20 \mathrm{~km}$ to the NW of the Bristol Coalfield (Fig. 1). In contrast with the Bristol Coalfield, the Forest of Dean coal measures are well exposed and the Forest of Dean Free Miners still mine coal in the area to this day. The stratigraphy of the Forest of Dean Coalfield is broadly comparable with that of the Bristol Coalfield (Fig. 3). The lowermost unit, the Trenchard Formation, consists of a quartzose sandstone with conglomerate at the base sourced from the ENE (Jones,
1972) and is restricted to the northern part of the basin (maximum thickness $120 \mathrm{~m})$. It is overlain by the Pennant Sandstone Formation that is represented by the Coleford Member consisting of $180-300 \mathrm{~m}$ of sandstone with subordinate mudstones and coals, which continue up to the Brazilly Coal. This unit thickens to the south, where it completely replaces the Trenchard Formation. Unlike the Trenchard Formation, the Coleford Member was sourced from the south (Jones, 1972). The Cinderford Member at the top of the sequence features $\sim 105 \mathrm{~m}$ of argillaceous strata with coals (historically termed the Household Coals) which are topped by $230 \mathrm{~m}$ of sandstones or interbedded sandstone and shales (historically termed the Serridge Sandstones). Another $25 \mathrm{~m}$ of argillaceous strata and the Worgreen coals lie at the top of the sequence. Red beds occur within the Cinderford Member.

The South Wales Middle and Lower Coal Measures formations are absent in the Forest of Dean and the Trenchard Formation unconformably overlies Viséan and older lithologies (Cleal \& Thomas, 1996). This angular unconformity probably represents the deformation which occurred in the late Bolsovian and Asturian during the first pulses of the Variscan uplift. It is probably contemporaneous with the Winterbourne Formation red measures that represent a switch in sediment source and the arrival of the Pennant Sandstone Formation in the Bristol Coalfield.

\section{Biostratigraphy and correlation}

Pendleton et al. (2012) demonstrated the presence of the following floral assemblages in the Bristol Coalfield: (i) those from the Winterbourne and Pennant Sandstone formations belong to the Laveineopteris rarinervis Subzone of the Paripteris linguaefolia floral zone, indicating a mid-late Bolsovian age; (ii) those of the Farrington Member (Grovesend Formation) belong to the Dicksonites plukenetii subzone of the Lobatopteris vestita floral biozone, indicating a late Asturian age; (iii) those of the uppermost 

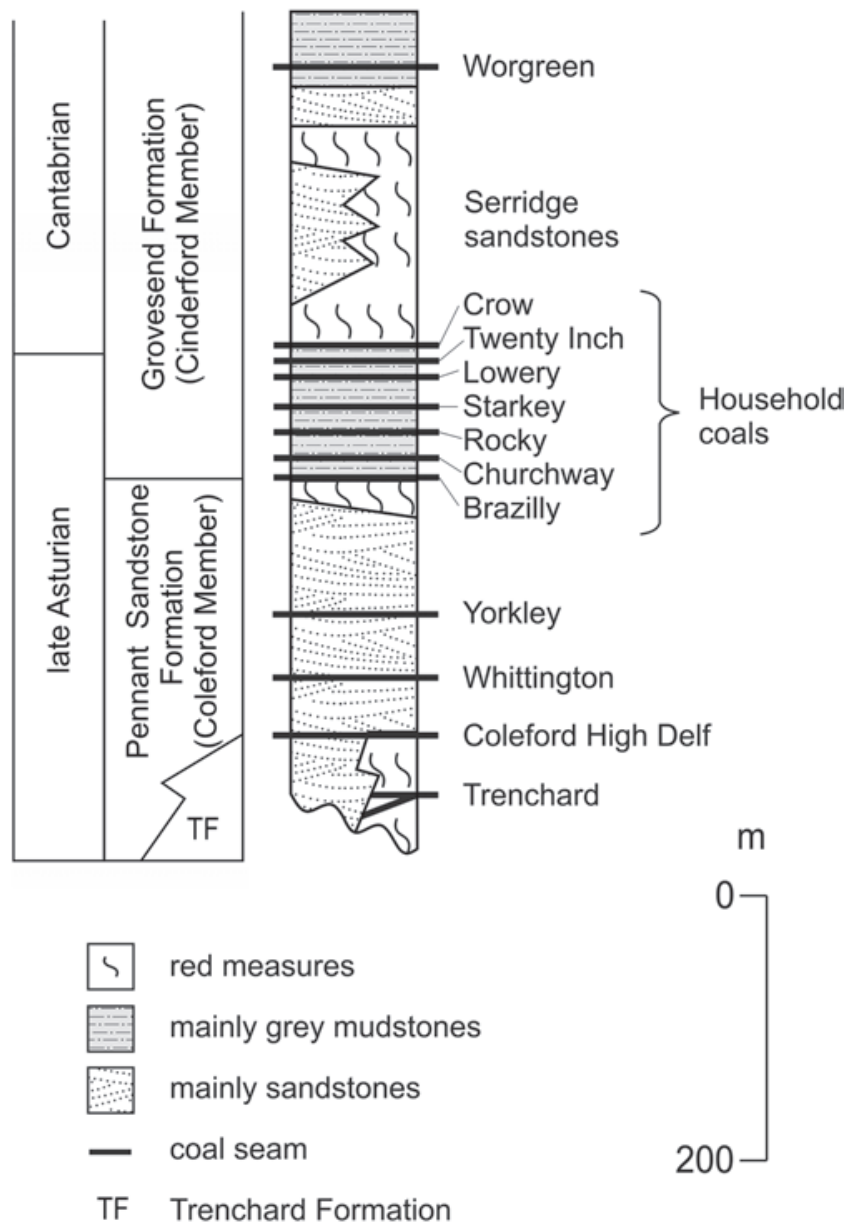

Fig. 3. Stratigraphy of the Forest of Dean Coalfield. Based on Waters et al. (2009) and Spinner (1965). Ages derived from plant macrofossils and palynology (Wagner \& Spinner, 1972; Cleal, 1991; 1997).

Publow Member (Grovesend Formation), from the Hursley Hill borehole beyond the southern outcrop limit of the coalfield, belong to the Odontopteris cantabrica Subzone, indicating a Cantabrian age. This suggests a stratigraphical gap between the Pennant Sandstone Formation and the Grovesend Formation that is probably related to a tectonic-induced hiatus referred to as the Leonian Phase of the Variscan Orogeny (sensu Wagner, 1966). This tectonic event also manifests itself as a hiatus in eastern South Wales (and marks the onset of coal-bearing deposition in the Forest of Dean, Severn, Newent and Oxfordshire coalfields (Cleal, 1986; 1987; 1997).

The Winterbourne Marine Band, which forms the basal limit of the Warwickshire Group, correlates with the Cambriense Marine Band which is roughly mid-Bolsovian in age and confirms the lower age constraint for this succession (Waters et al., 2009). Non-marine bivalves (Moore \& Trueman, 1937) and miospore biozones (Pendleton, personal data) also provide biostratigraphical ages confirming those derived from the megafloras. For a more detailed review of the biostratigraphy and correlation of the Bristol Coalfield, see Falcon-Lang et al. (2011) and Pendleton et al. (2012).

It is important to note that although the stratigraphical units can be correlated using lithostratigraphy this cannot be extrapolated in any way to imply coeval ages. The base of the Pennant Sandstone
Formation, for example, is markedly diachronous and youngs northward. In the southerly Somerset Coalfield the first Pennant lithologies occur below the Cambriense Marine Band and are of early Bolsovian age (Stubblefield \& Trotter, 1957; Green \& Welch, 1965). In the northerly Bristol Coalfield the base of the Pennant Sandstone is dated as mid- to late Bolsovian using palaeobotanical (Pendleton et al., 2012) and palynological (Pendleton, personal data) biozones. In the Forest of Dean, roof shale megafloras from the Coleford High Delf Coal, which roughly equates to the base of the Pennant Sandstone Formation, suggests a late Asturian age in this northernmost area (Wagner \& Spinner, 1972; Cleal, 1991; 1997). The red beds at the top of the Winterbourne Formation in Bristol probably correlate with the Deri Beds of South Wales (mid-/late Bolsovian), but despite their similar lithostratigraphic position, are older than the red beds at the top of the Trenchard Formation (late Asturian) in the Forest of Dean.

\section{MATERIAL AND LOCALITIES}

Forty-two coal samples were obtained from twenty coal seams, of which eight are considered stratigraphically important. These include named coal seams that were either commercially exploited in the past, or those that are mentioned by name in the Geological Survey Memoir and the accompanying map (1: 63 360-scale geological special sheet, British Geological Survey, 1972). These were the Hen Coal of the northern limb, one specimen from the Mangotsfield coals of Church Lane Colliery, Salridge Coal of the southern limb, the four main Parkfield Colliery seams and the High Coal of Coalpit Heath Colliery. These were sampled from in situ outcrops or localized spoil tips near historical exposures. Two unmapped coal seams were exposed during the widening of the A4174 Ring Road in $c$. 2007, which were collected and kindly donated by Nick Chidlaw.

Three of the lenticular coal seams, which occur sporadically in the Pennant Sandstone, were sampled; two from a disused quarry in the garden of Grove Cottage in Frenchay, and one from an outcrop in the garden of the cottage at 65, The Dingle in Winterbourne Down (see Fig. 2 and descriptions below for more field location details).

Six coal samples were obtained from Harry Stoke B borehole; one taken from material at British Geological Survey in Keyworth, and five from National Coal Board residues now housed at MB Biostratigraphy Ltd in Sheffield. A seam which Kellaway \& Welch (1993) correlated to the Hen Coal was included in these samples.

\section{Highly productive localities}

The Dingle, Winterbourne Down (Pennant Sandstone Formation; Mangotsfield Member). Well-preserved and abundant megaspores were recovered from a lenticular coal seam exposed at the top of a disused quarry wall in the back garden of number 65 on The Dingle in Winterbourne Down (Locality 4 [ST 656 794]). The coal seam is $\sim 45 \mathrm{~cm}$ thick and $\sim 4 \mathrm{~m}$ wide, extending for the full width of the exposure. The coal seam is on top of a $3 \mathrm{~m}$ thick bed of cross-bedded Pennant Sandstone, with an $80 \mathrm{~cm}$ bed of identical lithology resting atop it. A $15 \mathrm{~cm}$ thick sandstone parting occurs in the bottom quarter of the seam on the western side of the exposure, which dips to the east and merges with the top of the basal sandstone at the eastern limit of the exposure. This coal is interpreted as a localized area of peat generation on the margins of a channel, in a point bar-type setting, similar to that at Grove Cottage (see below). It is also possible this peat was infilling a large abandoned channel, whose dimensions cannot be appreciated based on the limited exposure. 


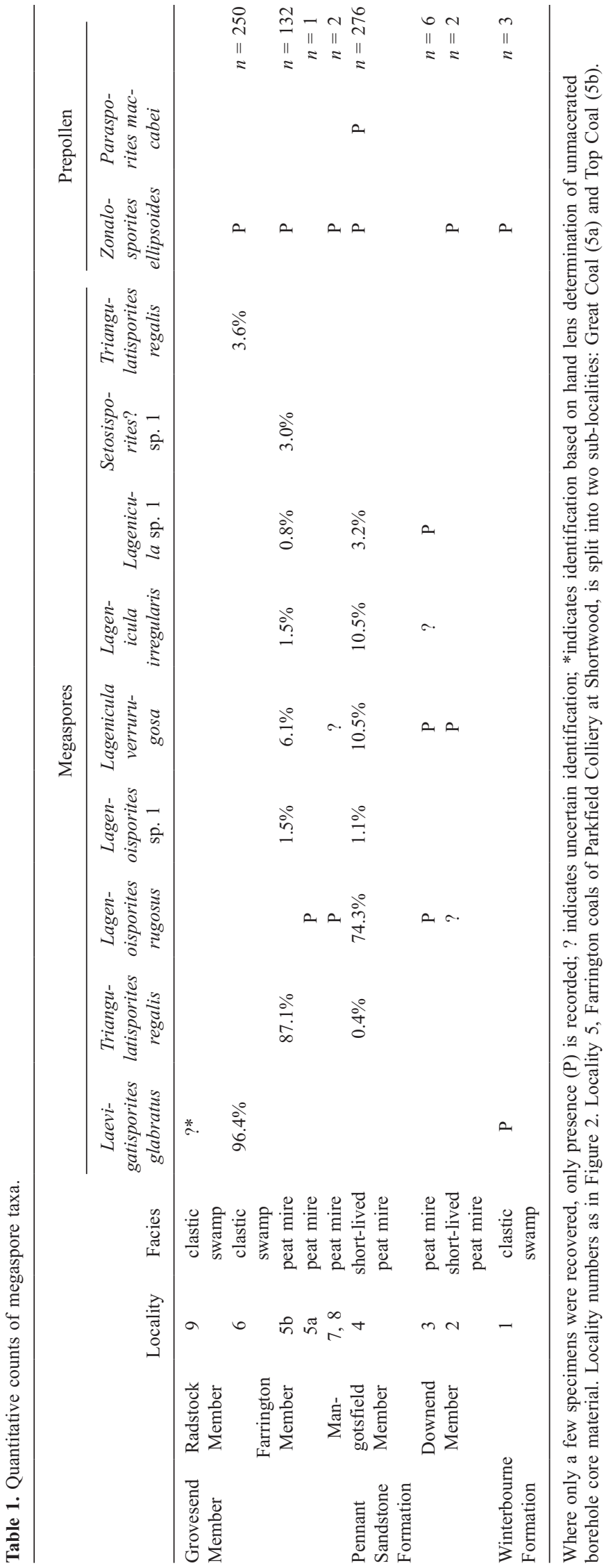

Farrington coals of Parkfield Colliery, Shortwood (Grovesend Formation; Farrington Member). Parkfield Colliery [ST 690 777], to the NW of Shortwood, worked the four economical coals of the Farrington Formation in this area between 1853 and 1936. These seams range from $0.5-1.5 \mathrm{~m}$ in thickness, and extend across $60-70 \mathrm{~m}$ of stratigraphy, and are also worked at Coalpit Heath nearly $5 \mathrm{~km}$ to the NW. In the past these coal seams were exposed in a now disused railway cutting (Locality 5 [ST 674 762]) that is now part of the Dramway cycle path. Original measurements along this section were made by Green \& Kellaway in 1948 and reported in Kellaway \& Welch (1993). These were all made using the northern side of the bridge, which now carries the B4465 over the A4174 at Shortwood, as a marker. Using these measurements, it was possible to measure out the section and locate the four Farrington Member coals: the Great, Hollybush, Top and Hard coals. These coals represent widespread and well-developed mire communities.

The outcrop of the Hard Coal was the only in situ coal found, but, more recently, even this seam has been completely obscured by overgrowth. At this locality the Hard Coal was found to be devoid of megaspores. Fragments of coal were found associated with a localized patch of landslipped material at the reported location of the Great Coal, which yielded poorly preserved megaspores (Locality 5a in Table 1).

Fragments of coal were also found in similar localized landslippages at the reported locations of the Hollybush and Top Coals. Although the fragments of the Hollybush Coal were devoid of megaspores, those from the Top Coal yielded abundant megaspores (Locality $5 \mathrm{~b}$ in Table 1). No trace was found of the two Rag Coals and the Stinking Coal, which occur stratigraphically above the four major seams.

Crookall's mudstones from Coalpit Heath Colliery (Grovesend Formation; Farrington Member). Crookall (1925a,b) catalogued the roof shale floras from major collieries, such as Coalpit Heath, Parkfield and Hanham. He mentions recovery of 'Lycopod megaspores' from five roof shale samples from Coalpit Heath Colliery (Locality 6 [ST 697 815]). Three of these samples now reside in the Bristol City Museum (registration number CG1573-1575), with the final specimen located in the Natural History Museum in London (registration number v16047). Small sub-samples of this material were acquired from each of these collections ( $\mathrm{Cg} 1675$ and v16047). Roof shales are traditionally interpreted as representing clastic swamps that fringed and infiltrated the peat mires, or alternatively as parautochthonous assemblages deposited during the final stages of peat mire drowning (Gastaldo et al., 1995).

\section{Locations with limited megaspore recovery Harry Stoke B Borehole (Winterbourne Formation).}

The Harry Stoke B borehole (Locality 1 [ST 6321 7816]) was drilled in 1950 at a location near Hambrook, between the University of the West of England campus and Junction 1 of the M32. The lowermost formation of the Warwickshire Group, the Winterbourne Formation, is exposed through $145 \mathrm{~m}$ of the borehole section. Although this borehole reportedly penetrated several coal seams, only fragmentary remains of one coaly shale at $59.03 \mathrm{~m}$ depth were found in the surviving borehole material. From the drilling records this layer represents one of several thin 
coaly layers, in a dark shaley mudstone, that rests on a $0.6 \mathrm{~m}$ thick grey fireclay. This coal, therefore, occurs in the upper portions of the Winterbourne Formation, $46.5 \mathrm{~m}$ below a coal thought to represent the Hen Coal, and $30 \mathrm{~m}$ below the point where persistent red mudstones become dominant. The sedimentology suggests that the sample represents a poorly drained clastic swamp, where short-lived and laterally restricted peat mires developed periodically. Unfortunately, the pre-prepared National Coal Board residues contained no megaspores, possibly due to differing preparation or sampling techniques.

Grove Cottage (Pennant Sandstone Formation; Downend Member). Two small ( $<5 \mathrm{~cm}$ thick, $\sim 1 \mathrm{~m}$ wide) lenticular coal seams occur in the Downend Member in a disused quarry surrounding the garden of Grove Cottage (Locality 2 [ST 640 772]) in Frenchay. The sedimentology of the outcrop is typical of the Pennant Sandstone Formation with a series of channel scours with patchy channel-lag conglomerates at the bases of metre-scale cross-bedded fluvial-deposited sandstones. Lateral accretion surfaces, festoon bedding and convolute bedding are also common, and are seen at the base or near the top of the larger sandstone beds. A bright coal caps one of the lateral accretion surfaces, and a dull coal appears to be filling a small conglomerate-filled scour, forming a lenticular bed with opposing inflexes (' $S$ '-shaped). This small scour appears at the base of the same lateral accretion surface packet as the previous coal. A limited megaspore assemblage was recovered from the dull coal. The bright coal contained abundant cuticle fragments, but no megaspores. These thin lenticular coals probably represent short-lived and localized peat-generating environments in close proximity to the braided fluvial system, possibly in a point bar-type setting.

High Coal of Coalpit Heath (Grovesend Formation; Farrington Member). Single specimens of Lagenoisporites rugosus? and Lagenicula verrurugosa were obtained from the High Coal of Coalpit Heath (Grovesend Formation; Farrington Member). The High Coal of Coalpit Heath was accessed via a drainage adit (Locality 7 [ST 668 796]), locally referred to as the Serridge Adit, beneath the Kendleshire golf course, with entrance to the adit via a manhole cover in a nearby field. This adit drains westward and enters the River Frome south of Huckford Quarry. At this partially flooded exposure the High Coal was measured as $1.7 \mathrm{~m}$ thick, with a red-stained roof shale almost certainly of secondary origin. This limited roof exposure was devoid of any visible plant fossils. The High Coal of Coalpit Heath represents a merging of two Parkfield coals: the Hollybush and Great coals. At this exposure, the High Coal clearly consists of $1.1 \mathrm{~m}$ of a more fissile coal that easily breaks into $<5 \mathrm{~mm}$ angular to sub-angular fragments, with $60 \mathrm{~cm}$ of more massive and hard coal above. Like the Farrington Member coals at Parkfield $3.8 \mathrm{~km}$ away, these coals represent widespread and well-developed mire communities. A sparse assemblage of megaspores was recovered from the very top of the coal seam, where the coal features widely dispersed brown and red streaks probably due to oxidation of pyrite. The same coal seam was also accessed $1.25 \mathrm{~km}$ to the NE, where it was briefly exposed during the summer of 2011 during building work in the basement of the Old Vicarage in Frampton Cotterell (Locality 8 [ST 673 807]). Here $50 \mathrm{~cm}$ of a soft black coal was exposed, which contained relatively high levels of pyrite compared to other Bristol coals. The visual appearance of the coal combined with high pyrite levels are similar to the coal exposed in the Serridge Adit, suggesting that the coal represents the upper portion of the High Coal and is equivalent to the Hollybush Coal of Parkfield.

Salridge Coal (Pennant Sandstone Formation; division between Downend and Mangotsfield members). Megaspores were recovered from three horizons associated with the Salridge Coal exposure at Locality 3 [ST 642 599]. The $0.85 \mathrm{~m}$ thick Salridge Coal overlies $1.75 \mathrm{~m}$ of alternating coal and mudstones layers, on top of a $7.3 \mathrm{~m}$ thick seat earth. Two megaspore assemblages were obtained from the interbedded coal and mudstones, and one assemblage recovered from the top of the Salridge Coal proper ( $85 \mathrm{~cm}$ thick at this locality). The outcrop of the Salridge can be traced for nearly $2 \mathrm{~km}$, and is probably an extension of the Mangotsfield coals of the Coalpit Heath basin $6 \mathrm{~km}$ to the north. Due to the thickness and extent of this coal seam, these megaspore assemblages are interpreted as being derived from a well-developed peat mire community. A fossil plant assemblage was recovered from the beige roof shale above the Salridge Coal and is discussed in Pendleton et al. (2012).

Hursley Hill borehole (Grovesend Formation; Radstock Member). A single mudstone sample with megaspores was obtained from the Radstock Member of the Hursely Hill borehole (Locality 9 [ST 618 657]) at $328.65 \mathrm{~m}$ depth. This is $\sim 49 \mathrm{~m}$ below the Asturian-Cantabrian boundary indicated by the megaflora (Pendleton et al., 2012). This mudstone is dark with several coaly layers, and is situated directly above a coal seam, according to the drillers logs. This sample, therefore, probably originated in a poorly drained clastic swamp. Although the sub-sample from this specimen yielded abundant and well-preserved miospores, only megaspore fragments were extracted after processing. Visual inspection of the megaspores on the original core material suggests Laevigatosporites glabratus, based on their size, laevigate exine and non-gulate contact areas. The miospore preparation is dominated by the corresponding microspore (Crassispora kosankei (Potonié \& Kremp) Bharadwaj, 1957a, b), which supports this identification.

\section{METHODS}

All coal samples were processed using standard palynological preparation techniques for extracting megaspores from coal. Schulze solution (65\% nitric acid supersaturated with potassium chlorate) was used as the oxidation agent. Oxidation of 20-90 minutes in Schulze solution, followed by a brief wash in $2 \%$ potassium hydroxide, was found to yield megaspores sufficient for examination and photography under the light microscope. Samples from fresh exposure and borehole were found to require 60-90 minutes of oxidation to yield translucent megaspores, whereas weathered coals from spoil tips and exposed outcrop reacted rapidly and required only 20 minutes of oxidation. Some weathered coal samples reacted so vigorously that diluted Schulze solution, in some cases in conjunction with cold water jacketing of the reaction beaker, was required to prevent almost explosive reactions. This phenomenon was also encountered by Schopf (1938) and Spinner (1965). It was noted by Spinner (unpublished thesis, University of Sheffield, 1964) that some megaspores shrank by up to $20 \%$ when allowed to dry. All measurements in this paper were made under a 
light microscope on specimens in water. It was found that pipetting megaspores with water on to a slide and covering with a cover slip provided optimal optics, and enabled specimens to then be mounted on stubs for scanning electron microscope (SEM) analysis.

Traditionally, miospores are separated arbitrarily from megaspores at a size boundary of $200 \mu \mathrm{m}$ in palynological studies. Megaspores for this study were extracted from the processed organic residue using a $180 \mu \mathrm{m}$ sieve. This size fraction included megaspores and large pteridosperm pollen (namely Zonalosporites and Parasporites). Miospore data from the samples discussed here are in preparation for publication (Pendleton, personal data). All processing was undertaken at the Palynological Research Facility at the University of Sheffield, UK.

\section{SYSTEMATIC PALAEONTOLOGY}

All taxa are adequately described in Spinner's (1965) work on the Forest of Dean; therefore, only comparisons, comments and illustration of the Bristol specimens will be dealt with in this section. Descriptive terms for megaspore morphology broadly follow those in Spinner (1965), which is based on recommendations made by the Commission Internationale Microflore Paléozoïque (Couper \& Grebe, 1961). All terms used can also be found in Punt et al. (2007). Due to the limited diversity, taxa will be listed alphabetically with no suprageneric classification system beyond differentiating megaspores and pteridosperm pollen. All field specimens are deposited in the Palynological Research Facility at the University of Sheffield, UK. Preparations from Natural History Museum and the Bristol City Museum and Art Gallery specimens were returned to the corresponding institution.

\section{MEGASPORES}

Genus Laevigatisporites (Ibrahim) Potonié \& Kremp, 1954

Type species. Laevigatisporites primus (Wicher) Potonié \& Kremp, 1954.

Affinity. Lycopsida; Sigillariaceae. The genus Laevigatisporites has been extracted from several cone species attributed to Sigillariaceae: Mazocarpon oedipternum Schopf, Sigillariostrobus gothani Bode (1928) and S. czarnockii Bocheński (1936) (reviewed in Spinner, 1965 and Balme, 1995). Studies of wall ultrastructure also support such an affinity (e.g. Hemsley \& Scott, 1991).

Laevigatisporites glabratus (Zerndt) Potonié \& Kremp, 1955 (Pl. 1, fig. 1; Pl. 2, figs 1, 2)

Affinity. Lycopsida; Sigillariaceae. L. glabratus has been extracted from the cone taxa Sigillariostrobus (Potonié, 1967; Balme, 1995) and Mazocarpon bensonii Pigg (Pigg, 1983).

Description. 10 specimens. Trilete megaspores, 1552(1593)1602 $\mu \mathrm{m}$ in diameter, with a circular to oval outline. Found in proximal-distal orientation. Laesurae 174(277)389 $\mu \mathrm{m}$; around two-fifths to three-fifths of the spore radius. Laesurae straight and may be open at the pole. Curvaturae present, but only faintly developed. Exospore laevigate.

Stratigraphic distribution. Latest Namurian to earliest Stephanian (Scott \& Hemsley, 1996). Reported range Trenchard to Worgreen coals in the Forest of Dean by Spinner (1965).
Occurrence. Winterbourne Formation (Harry Stoke B borehole) to Publow Member (Hursley Hill borehole).

Remarks. Laesurae considerably shorter than reported in Spinner (1965); in these specimens the laesurae extended between a half and two-thirds of the spore radius. The foveolate exospore (Pl. 1, fig. 1) mentioned in Spinner (1965) was also seen under SEM.

Genus Tuberculatisporites (Ibrahim) Potonié \& Kremp, 1954

Type species. Tuberculatisporites tuberosus Ibrahim, 1933.

Affinity. Lycopsida; Sigillariaceae. The genus Tuberculatisporites has been recovered from many different Sigillariostrobus strobili (Potonié, 1967; Balme, 1995) and Mazocarpon (Balme, 1995). Studies of wall ultrastructure also support such an affinity (e.g. Hemsley \& Scott, 1991).

\section{Tuberculatisporites brevispiculus (Schopf) Potonié \& Kremp, 1955 \\ (Pl. 1, fig. 2; Pl. 2, figs 3, 4)}

Description. 3 specimens. Trilete megaspores, 1713(1795)1824 $\mu \mathrm{m}$ in diameter. Found in proximal distal compression. Laesurae $267(301) 385 \mu \mathrm{m}$; marginally less than a third of the spore radius. Laesurae straight, often found torn open along their entire length. Curvaturae not present, but contact area is demarked by a thinning of the exospore in some specimens. Exospore ornamented; with 2(4) $6 \mu \mathrm{m}$ coni and slightly pointed verrucae which appear to be of more or less uniform size. Coni are spaced at intervals roughly equally or slightly exceeding their basal diameters. Larger ornament occurs outside of the contact area; consisting of a disc-like verrucae the basal component of which is circular in plan view and broadly rounded in profile view. These verrucae are $12(28) 53 \mu \mathrm{m}$ broad at the base, and less than $8 \mu \mathrm{m}$ in height. At the centre of the verrucae is a columellar structure (Schopf, 1938). These projections are fragile and, when well preserved, they appear to be conate to spinate in shape, originally around $8-10 \mu \mathrm{m}$ tall. They are more typically found compressed flat against the basal verrucae, or broken off so only small rounded discs remain. As with the ornament of the contact area, these verrucae with columellar structures are evenly distributed, and spaced at intervals roughly equal to or exceeding their basal diameters. The exospore between the ornament appears foveolate.

Stratigraphic distribution. Asturian to Stephanian in paralic basins of the UK (Spinner, 1965; 1966; Wagner \& Spinner, 1972), the Ruhr (Bharadwaj \& Kremp, 1955; Bharadwaj, 1957a, b) and North America (Schopf, 1938). In the limnic basins of northern France (Saar Lorraine) this species also occurs in the Langsettian/Duckmantian (Soyez, 1967; Loboziak, 1971; 1972). Reported range Trenchard to Worgreen coals in the Forest of Dean by Spinner (1965).

Occurrence. Upper Mangotsfield Member (65, The Dingle).

Remarks. Our specimens match the descriptions of the Forest of Dean species, the only difference being that the proximal coni and verrucae appear to be evenly spaced and do not decrease in size towards the pole. The species described as T. brevispiculus by 


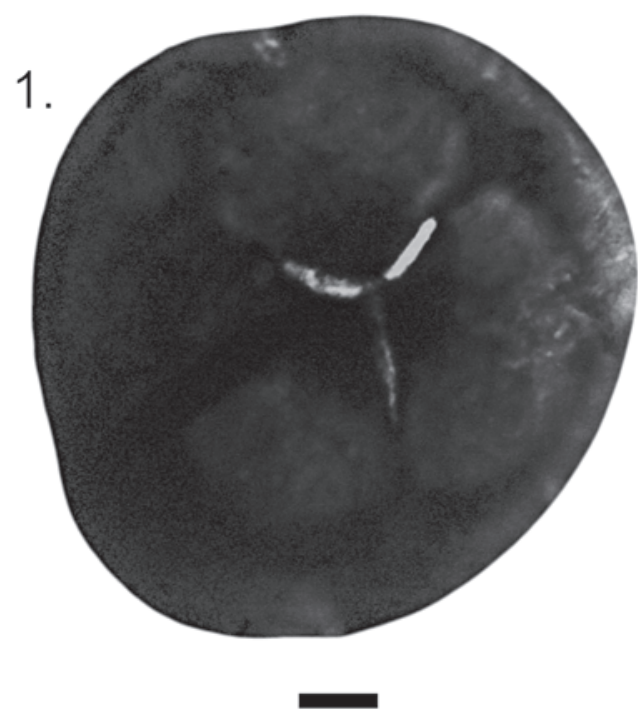

3.
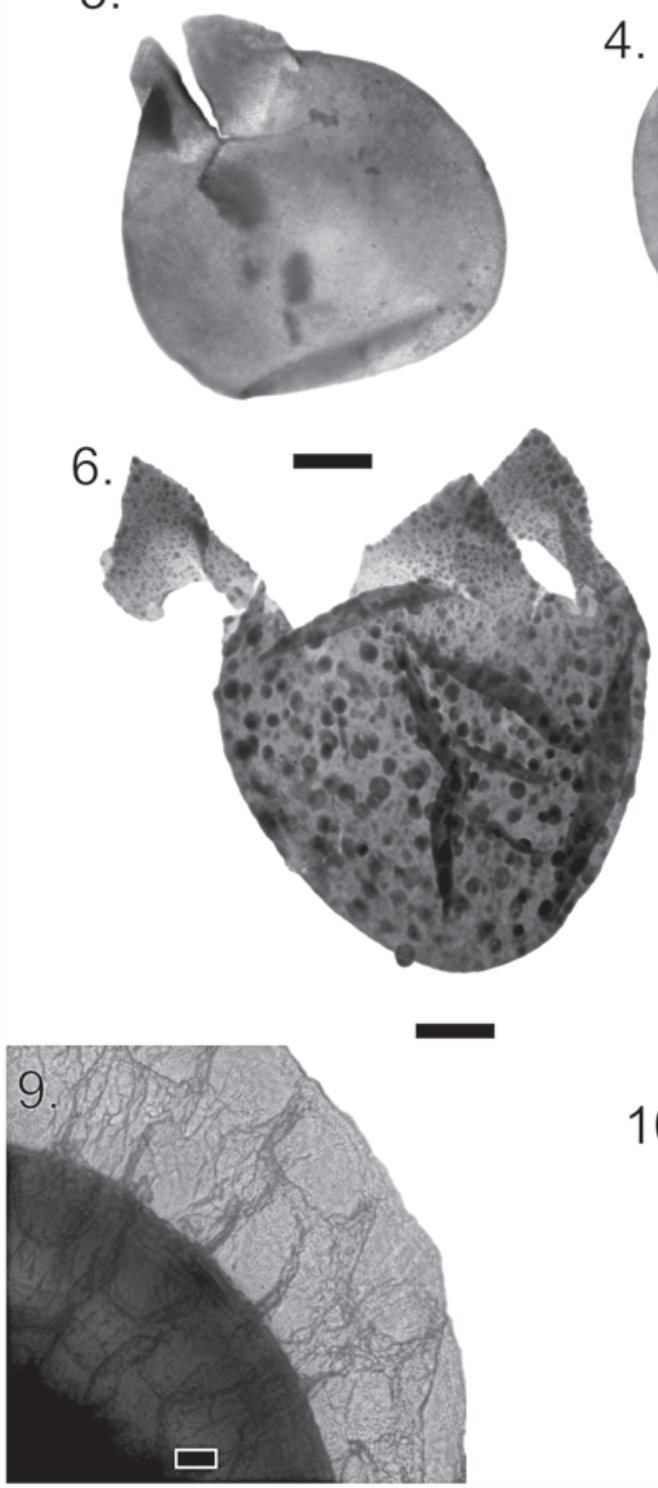

4.
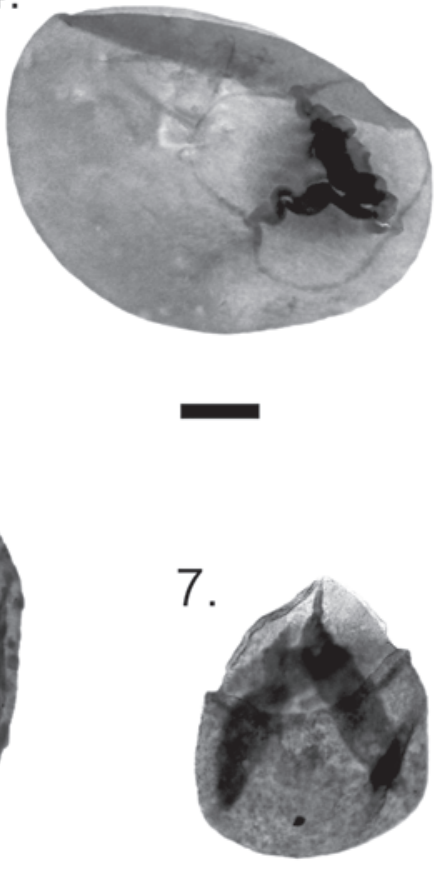

10.

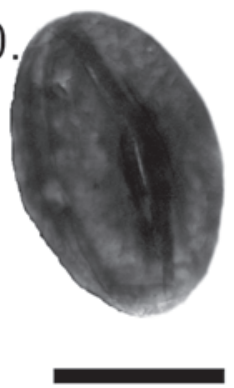

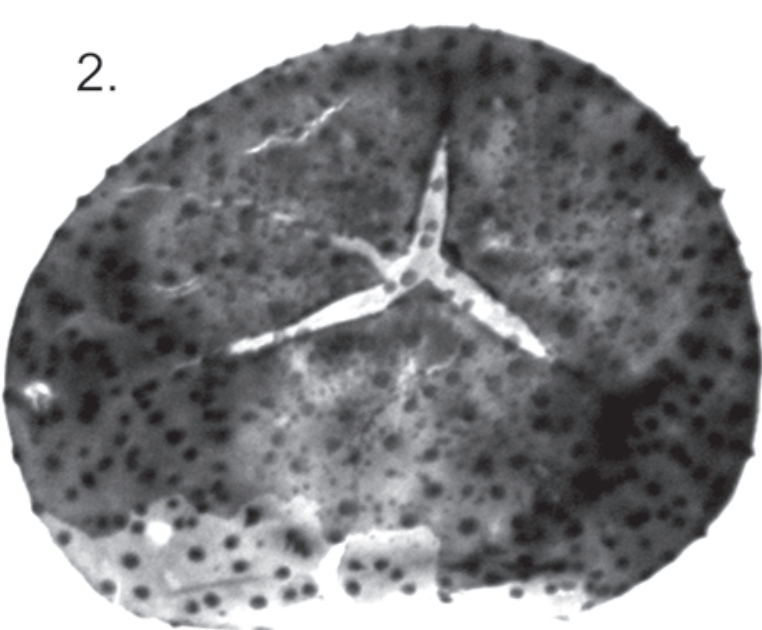
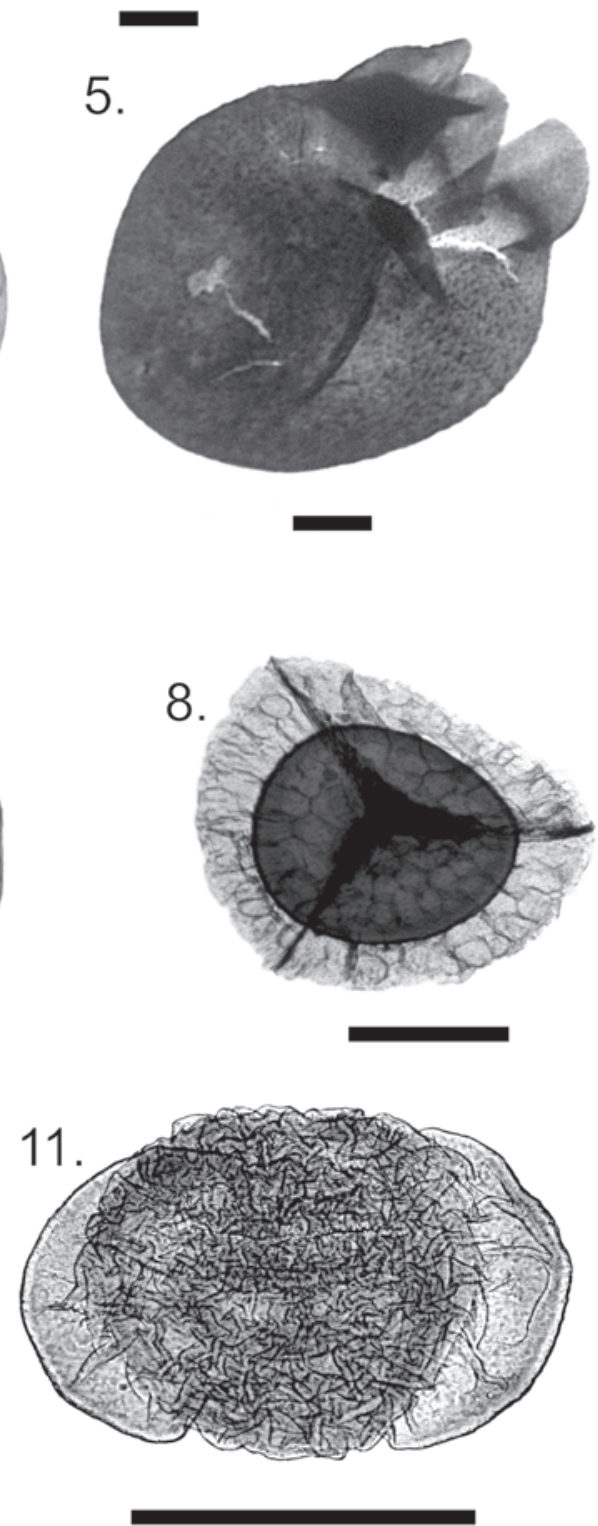
Horst (1955) featured larger ornament (40-65 $\mu \mathrm{m}$ diameter) which is not consistent with this species and is typical of T. mamilliarius. Horst (1955) provided no figures of these specimens. Dijkstra (1946) also included all Tuberculatisporites-type megaspores in 'Triletes' mamilliarius Barlett, maintaining that large size variations in ornament suggested designation of only one species and that Tuberculatisporites brevispiculus was, therefore, a synonym. Although some support for this large variation in ornament size has been provided by investigations of megaspores from sigillarian cones (Bocheński, 1936; Chaloner, 1953b), specimens exhibiting the relatively fine ornament of $T$. brevispiculus were not recovered. Re-investigation of the type material suggests that the type specimen of T. mamilliarius is distinct from T. brevispiculus (Arnold, 1961).

\section{Genus Lagenoisporites Potonié \& Kremp, 1954}

Type species. Lagenoisporites rugosus (Loose) Potonié \& Kremp, 1954.

Affinity. Lycopsida; Lepidocarpaceae. The genus Lagenoisporites has been reported in situ from a number of species of the cone Flemingites (Brack-Hanes \& Thomas, 1983; Balme, 1995). It has also been reported from the Permian bisporangiate taxon Azaniodendron (Rayner, 1986).

\section{Lagenoisporites rugosus (Schopf) Potonié \& Kremp, 1954} (P1. 1, fig. 3; P1. 2, figs 5-7)

Affinity. Lycopsida; Lepidocarpaceae. L. rugosus has been reported from Flemingites cones (Brack-Hanes \& Thomas, 1983; Balme, 1995).

Description. 20 specimens. Trilete megaspores, 435(911)1223 $\mu \mathrm{m}$ in diameter including apical prominence, with a circular to oval equatorial outline. Typically found in lateral compressions, where the gula gives the spore a distinctly flask shape. Laesurae often open and 239(431)645 $\mu \mathrm{m}$ long; roughly half of the spore radius. The contact areas are typically thickened in the region of the proximal pole. The gula is broader than it is tall; its width usually extending for two-thirds to almost the full width of the contact area. Curvaturae almost always form low arcuate ridges, rarely more than $20 \mu \mathrm{m}$ wide. Exospore is laevigate under the light microscope, with faint roughening of the contact areas. Under SEM the exospore is clearly foveolate, and the proximal roughness can be seen to be due to many irregular and closely spaced grana.

Stratigraphic distribution. Namurian $\mathrm{C}$ to Stephanian in Europe and North America (Scott \& Hemsley, 1996). Reported range Trenchard to Worgreen coals in the Forest of Dean by Spinner (1965).

Occurrence. Downend Member to Farrington Member (Grove Cottage, Salridge Coal, 65, The Dingle, Top and Great Coal at Parkfield Colliery and High Coal of Coalpit Heath).

Remarks. It is likely that the thickening of contact areas near the proximal pole is partly due to these closely packed and irregular grana, which are only visible under SEM. As noted in Spinner (1965), the differences between the ornamented Lagenicula and unornamented Lagenoisporites are rarely satisfactory and may be an effect of differing laboratory preparation techniques. Specimens with a granulate contact area were retained within this species due to the fact that previous authors had noted the thickening of the contact area; but as an SEM was not used in these early works it is likely that the grana were not noticed previously. Therefore, for the purposes of this study, Lagenoisporites rugosus is taken to include spores where grana occur in restricted areas near the proximal pole. In the Forest of Dean, Spinner (1965) differentiated Cystosporites based on the apical prominence being less pronounced, but the exospore being thicker in this region and featuring fine-scale ornament ('finely vermiculate to granulate'). In the Bristol specimens a complete spectrum was seen between obviously gulate megaspores, and those with a more subtle apical prominence which is slightly thickened in comparison to the rest of the exospore. For the purposes of this study, all this variation will be encompassed within $L$. rugosus. This seems logical as the forms grade into each other, and have both been found in cones affiliated with Lepidocarpaceae.

Lagenoisporites sp. 1

$$
\text { (P1. 1, fig. 4; P1. 2, fig. 8) }
$$

Description. 4 specimens. Trilete megaspores, 630(747)840 $\mu \mathrm{m}$ in diameter including apical prominence, with a circular to oval equatorial outline. Typically found in lateral and oblique compressions. Laesurae typically closed and 174(203)236 $\mu \mathrm{m}$ long; roughly

Explanation of Plate 1.

fig. 1. Laevigatosporites glabratus (Zerndt) Potonié \& Kremp, 1955. Crookall's mudstones from Coalpit Heath Colliery (Grovesend Formation; Farrington Member). SEM stub JLPBC-MEGA1, BCMAG. fig. 2. Tuberculatisporites brevispiculus (Schopf) Potonié \& Kremp, 1955. The Dingle, Winterbourne Down (Pennant Sandstone Formation; Mangotsfield Member). SEM stub JLPBC-MEGA2, USPRF. fig. 3. Lagenoisporites rugosus (Schopf) Potonié \& Kremp, 1955. The Dingle, Winterbourne Down (Pennant Sandstone Formation; Mangotsfield Member). SEM stub JLPBC-MEGA3, USPRF. fig. 4. Lagenoisporites sp. 1. The Dingle, Winterbourne Down (Pennant Sandstone Formation; Mangotsfield Member). SEM stub JLPBC-MEGA3, USPRF. fig. 5. Lagenicula verrurugosa Spinner, 1965. Crookall's mudstones from Coalpit Heath Colliery (Grovesend Formation; Farrington Member). SEM stub JLPBC-MEGA10, USPRF. fig. 6. Lagenicula irregularis Spinner, 1965. The Dingle, Winterbourne Down (Pennant Sandstone Formation; Mangotsfield Member). SEM stub JLPBC-MEGA9, USPRF. fig. 7. Lagenicula sp. 1, illustrating small and dense verrucae associated with the curvaturae. Farrington coals of Parkfield Colliery, Shortwood (Grovesend Formation; Farrington Member). SEM stub JLPBC-MEGA5, USPRF. figs 8, 9. Triangulatisporites regalis (Ibrahim) Potonié \& Kremp, 1955. Crookall's mudstones from Coalpit Heath Colliery (Grovesend Formation; Farrington Member): 8, proximal view. Slide JLPBC-MEGA10, BCMAG; 9, distal view. SEM stub JLPBC-MEGA6, NHM. fig. 10. Zonalosporites ellipsoides (Ibrahim) Ravn, 1986. Harry Stoke B Borehole (Winterbourne Formation). SEM stub JLPBC-MEGA8, USPRF. fig. 11. Parasporites maccabei Schopf, 1938. The Dingle, Winterbourne Down (Pennant Sandstone Formation; Mangotsfield Member). Slide JLPBC-MEGA11, USPRF. Scale bars $200 \mu \mathrm{m}$ for all images except fig. 9 where scale bar is $20 \mu \mathrm{m}$. BCMAG, Bristol City Museum and Art Gallery; NHM, Natural History Museum, London; USPRF, University of Sheffield Palynological Research Facility. 


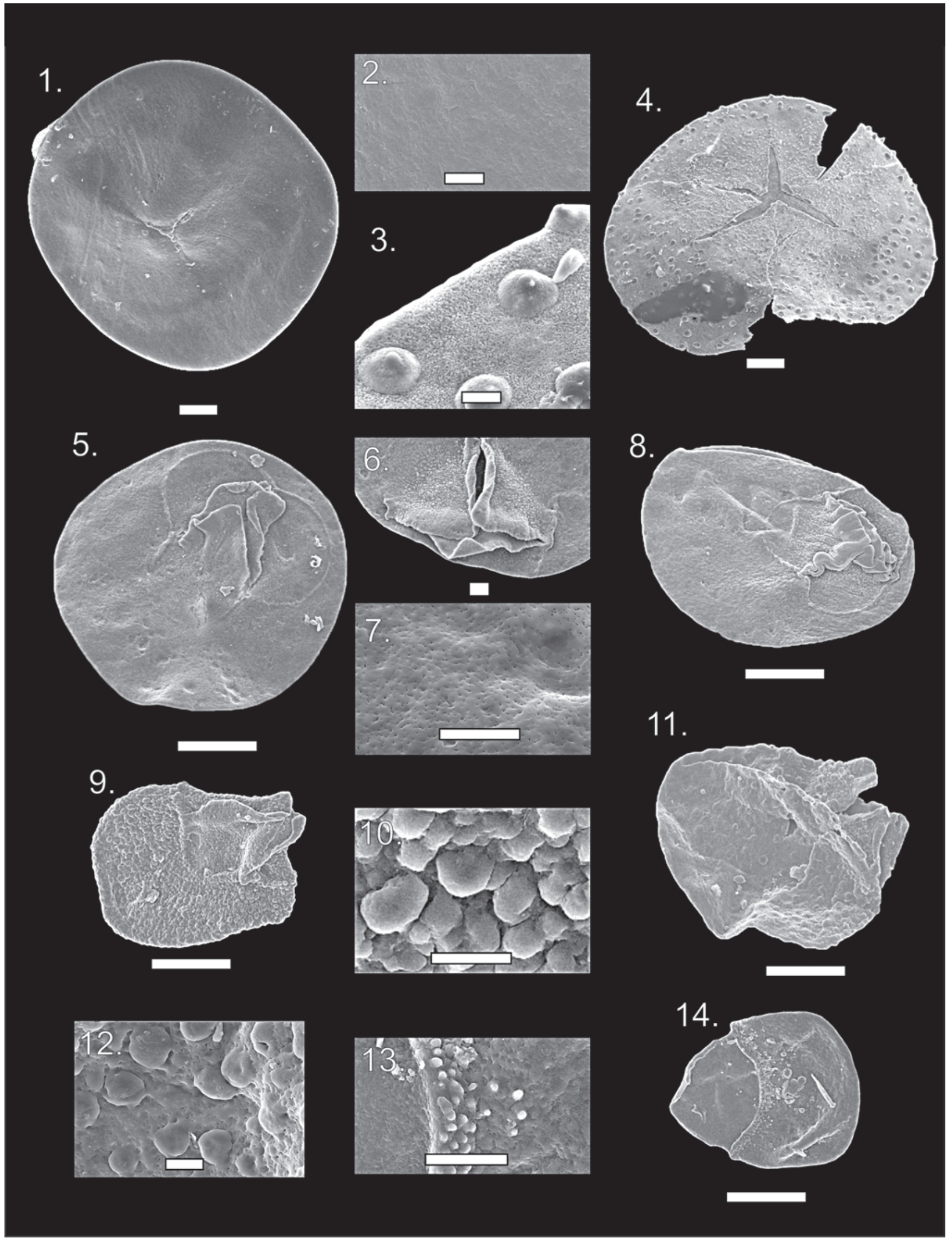


half of the spore radius. The contact areas are typically thickened in the region of the proximal pole. The gula is poorly developed, projecting only due to the undulate lips either side of the laesurae. Curvaturae almost always form low arcuate ridges, rarely more than $20 \mu \mathrm{m}$ wide. Exospore is laevigate under light microscope, with faint roughening of the contact areas. Under SEM the exospore is clearly foveolate, and the proximal roughness can be seen to be due to many irregular and closely spaced grana.

Occurrence. Mangotsfield Member to Farrington Member (65, The Dingle; Top Coal at Parkfield Colliery).

Remarks. Morphologically similar to Lagenoisporites rugosus; differing only in the generally smaller dimensions, poorly developed gula and convolute lips associated with the laesurae. One poorly preserved specimen shows subtle thickenings which may indicate the remains of ornament similar to Lagenicula verrurugosa.

Genus Lagenicula (Bennie \& Kidston) Potonié \& Kremp, 1954

Type species. Lagenicula horrida Zerndt, 1934.

Affinity. Lycopsida; Lepidocarpaceae. The genus Lagenicula has been reported in situ from a number of species of the cone Flemingites (Balme, 1995). Studies of megaspore wall ultrastructure also support such an affinity (e.g. Glasspool et al., 2000).

\section{Lagenicula verrurugosa Spinner, 1965}

(P1. 1, fig. 5; P1. 2, figs 9, 10)

Affinity. Lycopsida; Lepidocarpaceae. Reported in cones with Lagenoisporites rugosus by Dijkstra (1946) as reviewed in Spinner (1965).

Description. 11 specimens. Trilete megaspores, 820(953)1150 $\mu \mathrm{m}$ in diameter including apical prominence, with a circular to oval equatorial outline. Typically found in lateral compressions, where the gula gives the spore a distinctly flask shape. Laesurae often open and 200(257)315 $\mu \mathrm{m}$ long; roughly half of the spore radius. The gula is domed or conical in lateral compression, and collapses to form folds in polar compression so it may not project beyond the spore outline. Curvaturae almost always form low arcuate ridges, around $20 \mu \mathrm{m}$ wide. Exospore ornamented with dense verrucae $5(9) 15 \mu \mathrm{m}$ in diameter at the proximal pole and
$10(18) 32 \mu \mathrm{m}$ at the distal pole. Verrucae no more than $5 \mu \mathrm{m}$ in height. At the proximal pole the verrucae tend to have a more irregular and angular shape, whereas those at the distal pole are more rounded and may partially fuse at the base to produce pseudo-rugulae. Large scattered verrucae, up to $35 \mu \mathrm{m}$, may also occur on the curvaturae ridges.

Stratigraphic distribution. Reported range Trenchard to Worgreen coals in the Forest of Dean by Spinner (1965).

Occurrence. Downend Member to Farrington Member (Grove Cottage; 65, The Dingle; Top Coal at Parkfield Colliery).

Remarks. While sometimes slightly larger than the $500-900 \mu \mathrm{m}$ quoted by Spinner (1965), the size, shape, density and variation of the ornament conforms to the description. The presence of large scattered verrucae on the curvaturae ridge was also noted by Spinner (1965).

Lagenicula irregularis Spinner, 1965

(P1. 1, fig. 6; P1. 2, figs 11, 12)

Description. 12 specimens. Trilete megaspores, 740(1001)1340 $\mu \mathrm{m}$ in diameter including apical prominence, with a circular to oval equatorial outline. Typically found in lateral compressions, where the gula gives the spore a distinctly flask shape. Laesurae often open, and 230(282)470 $\mu \mathrm{m}$ long; roughly half of the spore radius. The gula is domed or conical in lateral compression, and collapses to form folds in polar compression so it may not project beyond the spore outline. Contact areas indistinct, and curvaturae are only partially discernible and are not marked by a clear ridge. Exospore ornamented with variably spaced verrucae; with round to oval outline in plan view and well-rounded apices in profile. Verrucae are biggest at the distal pole where they are $15(64) 84 \mu \mathrm{m}$ in basal diameter and 3(6)10 $\mu \mathrm{m}$ in height. Verrucae gradually diminish in size towards the proximal pole, and attain a relatively consistent basal diameter of 5(12)28 $\mu \mathrm{m}$ in the contact areas. Spacing between the verrucae varies with ornament size, being more or less equal to the basal diameter of the ornament in any given area.

Stratigraphic distribution. The only previous reports are from the Trenchard and Brazilly coals of the Forest of Dean by Spinner (1965).

Occurrence. Mangotsfield Member to Farrington Member (Salridge, 65, The Dingle and Top Coal at Parkfield Colliery).

\section{Explanation of Plate 2}

figs 1, 2. Laevigatosporites glabratus (Zerndt) Potonié \& Kremp, 1955. Harry Stoke B Borehole (Winterbourne Formation): 1, SEM stub JLPBCMEGA8, USPRF; 2, laevigate exospore. SEM stub JLPBC-MEGA, BCMAG. figs 3, 4. Tuberculatisporites brevispiculus (Schopf) Potonié \& Kremp, 1955. The Dingle, Winterbourne Down (Pennant Sandstone Formation; Mangotsfield Member). SEM stub JLPBC-MEGA2, USPRF: 3, illustrating restricted ornament in contact area; 4, illustrating verrucate ornament with central columellar structure. figs 5-7. Lagenoisporites rugosus (Schopf) Potonié \& Kremp, 1955. The Dingle, Winterbourne Down (Pennant Sandstone Formation; Mangotsfield Member): 5, SEM stub JLPBC-MEGA3, USPRF; 6, gula ornament. SEM stub JLPBC-MEGA3, USPRF; 7, punctate exospore. SEM stub JLPBC-MEGA4, USPRF. fig. 8. Lagenoisporites sp. 1. The Dingle, Winterbourne Down (Pennant Sandstone Formation; Mangotsfield Member). SEM stub JLPBC-MEGA3, USPRF. figs 9, 10. Lagenicula verrurugosa Spinner, 1965. Farrington coals of Parkfield Colliery, Shortwood (Grovesend Formation; Farrington Member). SEM stub JLPBC-MEGA5, USPRF: 9, gula; 10, illustrating dense verrucate exospore. figs 11, 12. Lagenicula irregularis Spinner, 1965. Farrington coals of Parkfield Colliery, Shortwood (Grovesend Formation; Farrington Member). SEM stub JLPBC-MEGA5, USPRF: 11, gula; 12, punctate exospore. figs 13, 14. Lagenicula sp. 1. Farrington coals of Parkfield Colliery, Shortwood (Grovesend Formation; Farrington Member). SEM stub JLPBC-MEGA5, USPRF: 13, illustrating small and dense verrucae associated with the curvaturae; 14, gula. Scale bars $200 \mu \mathrm{m}$ for whole megaspores (figs 1, 4, 5, 8, 9, 11, 14). Scale bars $20 \mu \mathrm{m}$ for images of exospore detail (figs 2, 3, 6, 7, 10, 12, 13). USPRF, University of Sheffield Palynological Research Facility. 
Remarks. Spinner (1965) also noted indistinct contact areas lacking curvaturae, as well as the uniform nature of the reduced ornament in the contact area. This ornament is notable for its consistent size when compared to the gradation of size from the distal pole to the edge of the contact areas.

Lagenicula sp. 1

(Pl. 1, fig. 7; Pl. 2, figs 13, 14)

Description. 6 specimens. Trilete megaspores, 940 (1070)1145 $\mu \mathrm{m}$ in diameter including apical prominence, with a circular to oval equatorial outline. Typically found in lateral compressions, where the gula gives the spore a distinctly flask shape. Laesurae often open and $230(282) 470 \mu \mathrm{m}$ long; roughly half of the spore radius. The gula is domed or conical in lateral compression, and collapses to form folds in polar compression so it may not project beyond the spore outline. Contact area delimited by clear curvaturae, which is marked by a ridge $10-15 \mathrm{~m}$ wide. Small baculae and verrucae $3(8) 8$ $\mu \mathrm{m}$ tall are developed on the curvaturae ridge and scattered verrucae may occur up to halfway towards the distal pole of the spore.

Stratigraphic distribution. Reported range Trenchard to Worgreen coals in the Forest of Dean by Spinner (1965).

Occurrence. Mangotsfield Member to Farrington Member (Salridge, 65, The Dingle and Top Coal at Parkfield Colliery).

Remarks. Conforms closely to the taxon described as Lagenicula arnoldii in Spinner (unpublished thesis, University of Sheffield, 1964) but not included in Spinner (1965).

Genus Setosisporites (Ibrahim) Potonié \& Kremp, 1954

Type species. Setosisporites hirsutus (Loose) Ibrahim, 1933.

Affinity. Lycopsida; Porostrobus-producing Selaginellaceaen lycopsids (Balme, 1995; Bek \& Leary, 2012). Megaspores of Setosisporites hirsutus have been recovered from Porostrobus cones along with Densosporites (Scott \& King, 1981; Leary \& Mickle, 1989). Studies of wall ultrastructure also support a lycopsid affinity (e.g. Hemsley \& Scott, 1991; Glasspool et al., 2000).

Setosisporites? sp. 1

(P1. 3, figs 1, 2)

Description. 2 specimens. Trilete megaspores, 602(691)781 $\mu \mathrm{m}$ in diameter including apical prominence, with a circular to oval equatorial outline. Typically found in lateral compressions, where the gula gives the spore a distinctly flask shape. Laesurae often open. Contact area delimited by the absence of ornament. Baculae $5(18) 25 \mu \mathrm{m}$ in length and 3(4) $6 \mu \mathrm{m}$ in basal width occur on the curvaturae, reducing in density towards the distal pole where they may be scattered or absent.

Occurrence. Farrington Member (Top Coal at Parkfield Colliery).

Remarks. Ornament of Lagenicula sp. 1 is restricted to the area around the curvaturae, and is verrucate but also features rare and very small baculae which are not comparable in size. Setosisporites pilatus Spinner, 1965 from the Forest of Dean is a similar size, has a Lagenicula-style gula and the baculate ornament that is smaller and denser on the curvaturae and that becomes larger and scattered distally. Due to the limited number and poor preservation of the Bristol species, no true pilate ornament was seen (baculae with clearly laterally expanded apices) so it does not appear to be the same species as Spinner reported. S. pilatus also has smaller ornament $(<15 \mu \mathrm{m})$

\section{Genus Triangulatisporites Potonié \& Kremp, 1954}

Type species. Triangulatisporites triangulatus (Zerndt) Potonié \& Kremp, 1954.

Affinity. Lycopsida; Selaginellaceae. Megaspores similar to Triangulatisporites triangulatus were extracted from cones of Sellaginellites suissei Zeiller by Zeiller (1886) and Chaloner (1954). This species has also been recovered from Selaginella gutbieri (Göppert) Thomas by Rößler \& Buschmann (1994). Studies of wall ultrastructure also support such an affinity (e.g. Cottnam et al., 2000).

Triangulatisporites regalis (Ibrahim) Potonié \& Kremp, 1955 (P1. 1, figs 8, 9; Pl. 3, figs 3-6)

Affinity. Lycopsida; Selaginellaceae (Zeiller, 1906; Chaloner, 1954; Bek et al. 2001; 2009).

Description. 9 specimens. Trilete, zonate megaspores 642 (714) $846 \mu \mathrm{m}$ in diameter. Inner body circular $408(469) 549 \mu \mathrm{m}$ in diameter, occupying $64(66) 67 \%$ of the total spore radius. Equatorial zone discordant with inner body shape, giving the megaspores a convexly triangular outline in polar view. Zona widest at the apices 133(148)172 $\mu \mathrm{m}$, and narrowest in the interradial regions $80(97) 120 \mu \mathrm{m}$. Megaspores typically preserved in proximal-distal orientation. Prominent ridge accompanies the laesurae, up to $15 \mu \mathrm{m}$ tall with an undulating crest. Ridge tallest where the laesurae reach

\section{Explanation of Plate 3.}

figs 1, 2. Setosisporites? sp. 1. Farrington coals of Parkfield Colliery, Shortwood (Grovesend Formation; Farrington Member). SEM stub JLPBCMEGA5, USPRF: 1, gula; 2, baculate ornament. figs 3-6. Triangulatisporites regalis (Ibrahim) Potonié \& Kremp, 1955. Crookall's mudstones from Coalpit Heath Colliery (Grovesend Formation; Farrington Member): 3, proximal view, SEM stub JLPBC-MEGA6, NHM; 4, distal view, SEM stub JLPBC-MEGA1, BCMAG; 5, proximal reticulum, SEM stub JLPBC-MEGA6, NHM; 6, distal reticulum, SEM stub JLPBC-MEGA1, BCMAG. fig. 7. Zonalosporites ellipsoides (Ibrahim) Ravn, 1986, proximal view. Harry Stoke B Borehole (Winterbourne Formation). SEM stub JLPBC-MEGA8, USPRF. figs 8-10. Parasporites maccabei Schopf, 1938. The Dingle, Winterbourne Down (Pennant Sandstone Formation; Mangotsfield Member). SEM stub JLPBC-MEGA7, USPRF: 8, proximal view; 9, proximal ornament; 10, distal view. Scale bars $100 \mu \mathrm{m}$ for whole megaspore and prepollen (figs 1, $3,4,7,8,10$ ). Scale bars $50 \mu \mathrm{m}$ for images of exospore detail (figs 2, 5, 6, 9). BCMAG, Bristol City Museum and Art Gallery; NHM, Natural History Museum, London; USPRF, University of Sheffield Palynological Research Facility. 


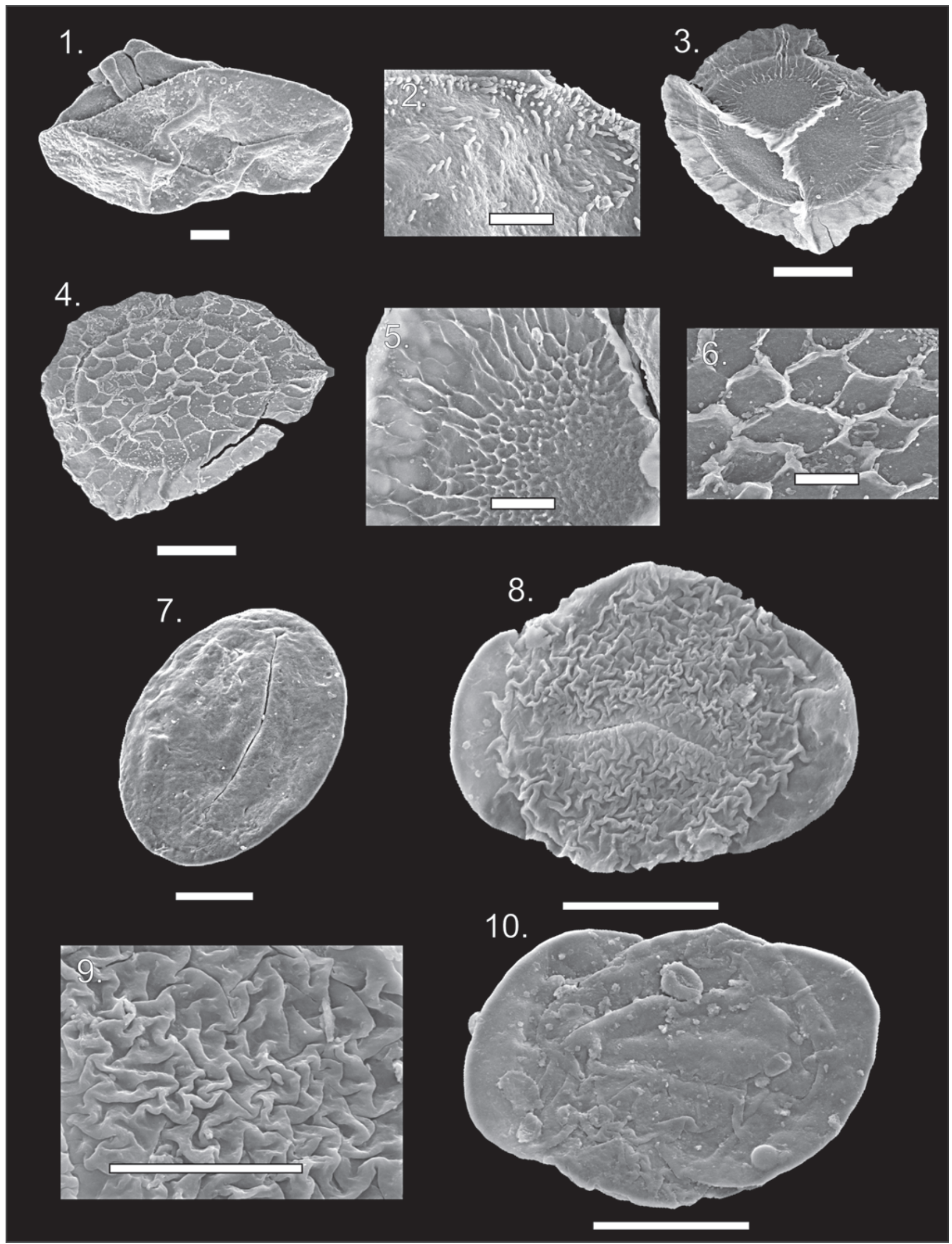


at the proximal pole, and diminish in height radially. Ridges extend to the equatorial outline defined by the zona. Contact areas ornamented with a reticulum; which is typically only preserved in localized patches at the junctions where muri fuse. Muri $\sim 2 \mu \mathrm{m}$ and polygonal lumina $\sim 10-15 \mu \mathrm{m}$ in the centre of the contact face, and become radially elongate towards the laesurae and edge of the inner body. At the edge of the inner body the muri become partially anastomosing verminiculae which extend on to the zona. Distally the polygonal lumina are bigger, 37(65) $85 \mu \mathrm{m}$, and muri more robust, $5(6) 12 \mu \mathrm{m}$, and therefore the distal reticulum is generally better preserved than the proximal reticulum. Distal lumina are also of a fairly consistent size over the inner body; but may become slightly radially elongate as they extend on to the zone. Between the reticulum, the exospore is laevigate.

Stratigraphic distribution. Duckmantian in the Ruhr (Potonié \& Kremp, 1956). Duckmantian to Asturian in the UK (Spinner, 1965; Turner \& Spinner, 1990) and Saar Lorraine (Piérart, 1965; Loboziak \& Coquel, 1968; Loboziak, 1971). Desmoinesian (Asturian) Herrin (No. 6) Coal of Illinois (Schopf, 1938). Reported range Trenchard to Worgreen coals in the Forest of Dean by Spinner (1965).

Occurrence. Farrington Member (Crookall's mudstone specimens from Coalpit Heath).

Remarks. Triangulatisporites triangularis (Zerndt) Potonié \& Kremp, 1954 is smaller, 560(600)960 $\mu \mathrm{m}$, with more robust muri which reach up to $40 \mu \mathrm{m}$ on the distal surface (Spinner, 1965).

Genus Zonalosporites Ibrahim, 1933

Type species. Zonalosporites vitatus Ibrahim, 1933.

Affinity. Medullosan pteridosperm: Zonalosporites pollen has been recovered from numerous medullosan pteridosperm pollen organs and is a distinctive enough pollen grain to be confidently associated with this group of plants (reviewed in Balme, 1995 and Taylor et al., 2009).

Remarks. Monoletes and Schopfipollenites are junior synonyms of Zonalosporites (see comments in Ravn, 1986).

Zonalosporites ellipsoides (Ibrahim) Ravn, 1986

(P1. 1, fig. 10; Pl. 3, fig. 7)

Affinity. Medullosan pteridosperm.

Description. 13 specimens. Oval pollen $295(350) 420 \mu \mathrm{m}$ long by $210(245) 270 \mu \mathrm{m}$ wide. Width $67(72) 81 \%$ of long axis of pollen. Single median longitudinal suture on proximal face $165(220) 360 \mu \mathrm{m}$ long, equal to $56(74) 85 \%$ of length of long axis. Suture may be distinct or obscure, and may have a deflection about its midpoint. Convex nature of the distal surface often leads to longitudinally orientated compression folds on the distal surface. Typically there are two of these; one each side of the distal convexity. Exine is laevigate to punctate.

Stratigraphic distribution. Pendleian to Asturian in Britain (Smith \& Butterworth, 1967). Bolsovian to Stephanian in SaarLoraine (Bharadwaj, 1957b).
Occurrence. Winterbourne Formation to Farrington Member (Harry Stoke B to Top Coal of Parkfield).

Remarks. Winslow (1959) and Millay et al. (1978) also note that the proximal suture may have a median deflection very similar to that of Parasporites maccabei Schopf.

Genus Parasporites Schopf, 1938

Type species. Parasporites maccabei Schopf, 1938.

Affinity. Medullosan pteridosperm: Parasporites has been recovered in situ from the medullosan pteridosperm pollen organ Parasporotheca (reviewed in Taylor et al., 2009).

Parasporites maccabei Schopf, 1938

(Pl. 1, fig. 11; Pl. 3, figs $8-10$ )

Affinity. Medullosan pteridosperm. Extracted from Parasporatheca leimanii Dennis \& Eggert, 1978 (Dennis \& Eggert, 1978).

Description. 13 specimens. Bi-pseudosaccate pollen with a circular to oval body $179(209) 246 \mu \mathrm{m}$ by $180(205) 220 \mu \mathrm{m}$ occupying $67(74) 80 \%$ of the spore width along the long axis of the grain. Generally haploxylonoid, but may be slightly diploxylonoid; long axis 243(282) $310 \mu \mathrm{m}$. Proximal suture variable; monolete with median deflection and incipient trilete conditions are seen on 9 specimens. Suture 103(120)139 $\mu \mathrm{m}$ long, 50(57)66\% of body long axis. Proximal ornament of pollen body consists of a network of interconnecting, convolute rugulae $2(6) 10 \mu \mathrm{m}$ wide. These rugulae may almost abut against each other, or be separated by up to $4 \mu \mathrm{m}$. Two generally crescentic pseudosacci, lacking endoreticulation, are attached to the distal side of the equator. Pseudosacci dimensions 163(176)192 $\mu \mathrm{m}$ by 64(83)107 $\mu \mathrm{m}$.

Stratigraphic distribution. Rock Island (base of Desmoinesian) to Calhoun Coal (uppermost Missourian) of Illinois (Millay et al., 1978). This suggests an Asturian to Barruelian range. This pollen has not been reported previously in Europe.

Occurrence. Mangotsfield Member (65, The Dingle, Winterbourne Down).

Remarks. Millay et al. (1978) suggest that the nature of the proximal sutures is evidence for a preformed line of weakness, which is to be expected if proximal rupture occurs during germination.

\section{BIOSTRATIGRAPHY}

A limited biostratigraphy for the Bristol Coalfield can be drawn up using the ranges of the megaspores and large pollen grains (Fig. 4). Tuberculatisporites brevispiculus is restricted to the Asturian in the paralic basins of Western Europe and equivalent Desmoinesian strata in Illinois (Schopf, 1938; Potonié \& Kremp, 1956; Bharadwaj, 1957a, $b$; Spinner, 1965; 1966). This taxon occurs approximately in the middle of the Mangotsfield Member. This suggests that the Bolsovian-Asturian Boundary lies within the Mangotsfield Member. Parasporites maccabei is known to range from the lower Desmoinesian (Asturian) to the latest Missourian (Barruelian) in NE North America (Millay et al., 


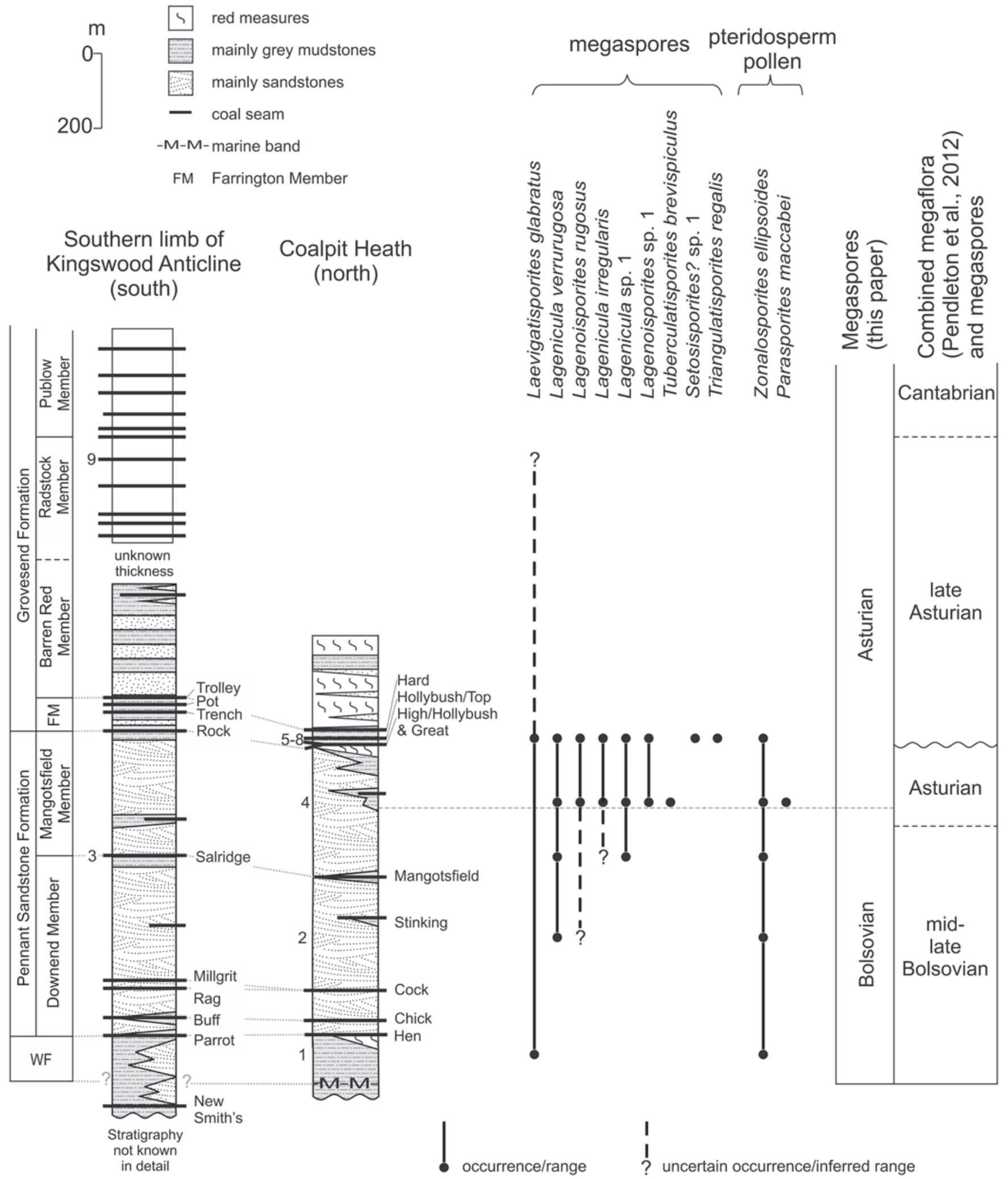

Fig. 4. Megaspore composite stratigraphic ranges for the Warwickshire Group of Bristol. Position of the Bolsovian-Asturian boundary using the new megaspore biostratigraphy and megafloral biostratigraphy from Pendleton et al. (2012). Locality numbers (as in Fig. 2) to left of lithostratigraphic columns. 
1978). The presence of high numbers of this pteridosperm pollen in the middle of the Mangotsfield Member also supports an Asturian age for this horizon.

The only productive plant fossil horizon from the Mangotsfield Member examined by Pendleton et al. (2012) featured no biostratigraphically useful taxa and thus provided no evidence for Asturianaged rocks at the top of the Pennant Sandstone. Assemblages from the Mangotsfield coals and Salridge Coal contain the following plant species which do not extend beyond the Laveineopteris rarinervis Subzone: Laveineopteris tenuifolia (Sternberg) Cleal et al.,1990, Lobatopteris miltonii (Artis) Wagner, 1958 and Laveineopteris dussartii (Laveine) Laveine, 2005 and, therefore, indicate a Bolsovian age. Several stratigraphically significant miospore species have their first occurrence near the base of Mangotsfield Member in the Coalpit Heath Basin: Cadiospora magna Kosanke, 1950, Mooreisporites inusitatus (Kosanke) Neves, 1958 and Savitrisporites camptotus (Alpern) Venkatachala \& Bharadwaj, 1964 accompanied by a general increase in Thymospora spp.. These taxa are indicative of the OT biozone of Clayton et al. (1977), the base of which just pre-dates the Bolsovian-Asturian boundary. Taking together evidence from megaflora, megaspore and miospore biozonation, it seems likely that the base of the Asturian is within the lower portion of the Mangotsfield Member.

\section{PALAEOECOLOGY}

\section{Palaeoecological considerations}

Quantitative megaspore data for each locality are given in Table 1. The assemblage from the poorly drained coastal plains of the Winterbourne Formation features few megaspores, with only those of a sigillarian affinity (Laevigatosporites glabratus) recovered. Pteridosperm pollen (Zonalosporites) is also common. Sigillarian dominance in these types of coastal plain is typical of the Westphalian of Euramerica (DiMichele \& Phillips, 1994). Miospore assemblages from the same horizon (Pendleton, personal data) are co-dominated by cordaite pollen $(31 \%)$ and lepidodendrid spores (27\%), with low numbers of sigillarian spores $(3.5 \%)$. The absence of lepidodendrid megaspores in the assemblage, therefore, seems unusual. However, the diverse and well-preserved miospore assemblage suggests that a simple preservational bias between more robust sigillarian megaspores and relatively less robust lepidodendrid megaspores is unlikely in this case. A taphonomic bias manifested as low sigillarian miospore abundance in coastal plain assemblages despite dominance among plant megafossils has been reported for the Joggins Formation of Nova Scotia (Hower et al., 2000; Falcon-Lang et al., 2006) and may be more broadly comparable.

Megaspore assemblages from the localized and short-lived point-bar peat mires of the Pennant Sandstone Formation are dominated by lepidodendrid megaspores (Lagenoisporites and Lagenicula) with high levels of pteridosperm pollen (Parasporites and/or Zonalosporites). Miospore assemblages from the Downend Member coal at Grove Cottage (Pendleton, personal data) are dominated by lepidodendrid spores (50\%), with subordinate tree-fern spores $(21 \%)$ and calamitalean spores (16\%). The Mangotsfield Member coal (The Dingle) assemblage is dominated by tree-fern spores $(30.5 \%)$ with subordinate calamitalean spores $(20.5 \%)$ and fern spores (18\%), with only $8.5 \%$ lepidodendrid spores. Differences between dominance patterns in the miospore counts are likely to be at least partially due to subtle differences in depositional setting and, therefore, corresponding vegetational composition. However, the temporal differences between these Bolsovian (Downend Member) and early Asturian (uppermost Mangotsfield Member) will almost certainly play a crucial role with the differences reflecting tectonic- and/or climatic-driven reductions in species diversity near the end of the Bolsovian (Cleal, 2007; Opluštil \& Cleal, 2007).

Megaspore assemblages from the late Asturian Farrington Member peat mires feature only lepidodendrid megaspores (Lagenoisporites and Lagenicula) and pteridosperm pollen (Zonalosporites), which are abundant and well-preserved in the Top Coal at Parkfield Colliery. Miospore assemblages (Pendleton, personal data) feature typical Asturian dominance of small fern spores (22\%), tree-fern spores (18.5\%) and calamitalean spores $(15.5 \%)$. Lepidodendrid spores make up only $10.5 \%$ of the palynomorphs.

The assemblage from the roof shale of a Farrington Member coal seam, reflecting the flora from clastic swamps fringing the peat mires, is dominated by sigillarian megaspores (Laevigatosporites glabratus), with megaspores from herbaceous selaginellids (Triangulatisporites regalis) and pteridosperm pollen (Zonalosporites ellipsoides). The miospore assemblage (Pendleton, personal data) is also dominated by sigillarian miospores (Crassispora kosankei, 79.5\%). However, no selaginellid miospores (Cirratriradites) were found in the preparations. Sigillarian dominance in the megaspore preparations is also seen in the clastic swamps of the Radstock Member, and in the poorly drained coastal plain of the Winterbourne Formation.

Pteridosperms, specifically those which produce Zonalosporites-type pollen, occur in all of the megaspore-bearing horizons of the Warwickshire Group. Miospore preparations of both coals and siliciclastics (Pendleton, personal data) show that pteridosperm pollen (Zonalosporites and Wilsonites) ranges throughout the Warwickshire Group occurring in almost every miospore-yielding horizon investigated. This suggests that these plants were widespread across both the peat mire and clastic environments. Pteridosperm anatomy and distribution support the suggestion that these plants colonized a wide variety of wetland habitats with mineral-rich substrates, from clastic floodplains and saturated stream sides to comparatively well-drained levees, but are rarely found in peat-generating areas (DiMichele et al., 2006). Although ecologically widespread, pteridosperm pollen rarely accounts for more than $1 \%$ of the total miospore preparations and is always subordinate in the megaspore fraction. Several factors have been proposed for this dearth of pollen grains compared to the abundance of their fossilized foliage. These generally involve analogies with the infrequent reproduction of their nearest living relatives, the cycads, and their limited dispersal potential in water based on modelling studies (Schwendemann et al., 2007).

Parasporites has prominent pseudosacci and is likely to have been wind dispersed. Its presence in the thin coal bed of the upper Mangotsfield Member is the first record of this taxon in the British Isles. Although this species has been extracted from pollen organs, it has not been possible to link these with the parent plant. Thus, we know that this pollen derives from a pteridosperm, but we do not know the nature of the parent plant. The concentration of Parasporites in this point bar was probably derived from pteridosperms living on the margins of this localized peat-generating area, with the wind-dispersed pollen being blown into the mire. 


\section{Comparison with the Forest of Dean - shedding more light on palaeoecological signals}

Spinner (1965) documented megaspore assemblages from the Forest of Dean coal seams, and several corresponding roof shales. Most of the coal seams show a dominance of lepidodendrid megaspores (Lagenoisporites and Lagenicula) similar to that seen in the coals of the Bristol Coalfield. In the Forest of Dean the coals preserve a much more diverse megaspore assemblage, including Valvisisporites (reported in situ from a Polysporia cone assigned to the Chaloneriaceae (Pigg \& Rothwell, 1983)), Zonalesporites (reported in situ from Sporangiostrobus, a cone also assigned to the Chaloneriaceae (Pigg \& Rothwell, 1983)), Cystosporites (lepidodendrid) and Triangulatisporites (selaginellid). Triangulatisporites (selaginellid) are often subordinate to lepidodendrid megaspores (Lagenosisporites and Lagenicula) (Spinner, 1965). However, in Bristol the only accessory megaspore seen in the coals is rare Tuberculatisporites brevispiculus at the top of the Mangotsfield Member.

Peat mires generally follow a predictable pattern of hydrological evolution; from initial topogenous (planar) through to ombrogenous (domed) mire. This drives a corresponding evolution in the vegetation signal that can be seen in both the fossil plant assemblages (DiMichele \& Phillips, 1994) and the corresponding palynological assemblages (Smith, 1957). Initially lepidodendrids are dominant in the flooded planar mire ('Lycospore Phase'; Smith, 1957), with peat accumulation eventually leading to a better-drained domed mire that is dominated by stunted vegetation and sub-arborescent lycopsids ('Densospore Phase'; Smith, 1957). This model can be used to explain a lot of the differences between the Forest of Dean and Bristol assemblages. The Forest of Dean assemblages were obtained from thick coal seams that are laterally extensive and traceable over the entire coalfield. The plant communities that formed these would have been well established and, therefore, probably more diverse, than those in the disturbed floodplains of the Winterbourne Formation and the short-lived point-bar ecosystems of the Pennant Sandstone Formation.

The Top Coal of Bristol, along with the restricted assemblage from the Salridge Coal, represents the only laterally extensive peat mire megaspore assemblages derived from the Bristol Coalfield. Like the Forest of Dean seams these are dominated by lepidodendrid megaspores (Lagenoisporites and Lagenicula). However, like the Pennant Sandstone point-bar coals they do not feature the array of herbaceous and sub-arborescent lycopsid accessory taxa present in the Forest of Dean. The Top Coal miospore preparations show dominance of ferns and tree-ferns (Pendleton, personal data). Forest of Dean seams, which are fern and tree-fern dominated - the Brazilley to Starkey seams - also have similar megaspore assemblages where sub-arborescent and herbaceous lycopsid megaspores are not present in the assemblage (Spinner, 1965). This is presumably due to better-drained conditions in the mires favouring ferns and tree-ferns over lycopsids.

Clastic mires (roof shales) on the fringes of a laterally persistent mire, which produced the roof shales of the Yorkley Coal in the Forest of Dean, have megaspore assemblages dominated by a sub-arborescent lycopsid (Zonalesporites) (Spinner, 1965). Miospore preparations from this horizon are dominated by the corresponding microspores: Densosporites (data from Spinner, unpublished thesis, University of Sheffield, 1964). The roof shales of the Brazilly and Twenty Inch contained a similar lepidodendrid-dominated assemblage as the associated coal seams (Spinner, 1965). The Bristol roof shale indicates that the clastic fringes of one of the Farrington Member peat mires was dominated by sigillarian (Laevigatisporites) megaspores, with subordinate herbaceous lycopsid megaspores (Triangulatisporites). Unfortunately, it is not known which coal seam Crookall acquired this specimen from so further comparison is not possible.

\section{CONCLUSIONS}

1. Abundant and well-preserved megaspore assemblages were obtained from the Warwickshire Group of the Bristol Coalfield, representing four distinct depositional settings: poorly drained and disturbed coastal plain; periodically established point-bar mires associated with active braidplains; temporally and laterally persistent peat mires; and clastic swamps on the fringes of the well-developed peat mires.

2. Sigillarian megaspores dominate the better-drained and disturbed settings of the coastal plains and clastic mire fringing peat mires. Selaginellid megaspores are also found in the clastic swamps.

3. Lepidodendrid megaspores dominate both the welldeveloped peat mire, and the relatively short-lived point-bar mire assemblages.

4. The biostratigraphically important taxa, Tuberculatisporites brevispiculus and Parasporites maccabei, suggest that the upper Mangotsfield Member is Asturian in age. This diminishes the duration of the stratigraphic gap reported in Pendleton et al., (2012).

5. Megaspore assemblages reported from the Forest of Dean Coalfield generally feature a more diverse collection of taxa compared to those reported here from the Bristol Coalfield. These differences are probably driven by the difference in the depositional environments sampled in the Forest of Dean (thick and laterally extensive economic coal seams reflect widespread and well-developed mire communities) and those available for sampling in the Bristol Coalfield (dominated by clastic swamps and small-scale and short-lived peat mires, with little available material from well-developed mires).

6. Parasporites maccabei is recorded here for the first time in Europe. Here this species is associated with the periodically established point-bar mires.

\section{ACKNOWLEDGEMENTS}

JLP acknowledges a NERC-funded research studentship held at the University of Sheffield, a CASE award with the National Museum of Wales Cardiff, supervised by Charles Wellman and Christopher Cleal. We would like to thank the following: Mike Howe and Scott Renshaw (BGS, Keyworth) for facilitating access to the Harry Stoke B borehole; Tim Ewin and Peta Hayes (NHM, London) for their help locating material at the Natural History Museum, London; Duncan McLean and David Bodman (MB Stratigraphy Ltd, Sheffield) for allowing access to samples of the NCB coal residues in their care; David Hardwick and the rest of the South Gloucestershire Mining Research Group for facilitating access to the High Coal in the Serridge drainage adit and Old 
Vicarage and for their continued sample donations and support; Nick Chidlaw for his valuable field observations and kind donation of samples taken during the A4174 widening; Holly Duffy (University of Sheffield) for her assistance in slide mounting and initial photography of specimens; Alan Spencer (Imperial College London) for field work assistance; Jiří Bek and an anonymous reviewer for their valuable feedback and support.

\section{Manuscript received 9 January 2012 \\ Manuscript accepted 2 April 2012}

Scientific Editing by John Marshall

\section{REFERENCES}

Arber, E.A.N. 1912. On the fossil flora of the Forest of Dean Coalfield (Gloucestershire), and the relationships of the coalfields of the west of England and South Wales. Proceedings of the Royal Society of London $B$, 84: 545-545.

Arnold, C.A. 1961. Re-examination of Triletes superbus, T. rotatus and $T$. mamillarius of Bartlett. Brittonia, 13: 245-252.

Balme, B.E. 1995. Fossil in situ spores and pollen grains: An annotated catalogue. Review of Palaeobotany and Palynology, 87: 81-323.

Bateman, R.M. \& DiMichele, W.A. 1994. Heterospory: The most iterative key innovation in the evolution of plants. Biological Reviews, 69: 345-417.

Bek, J. \& Leary, R.L. 2012. Porostrobus nathorstii (Leary \& Mickle) emend. and its spores from the Namurian of Illinois, USA. Bulletin of Geosciences, 87: 45-52.

Bek, J., Opluštil, S. \& Drábková, J. 2001. Two species of Selaginella cones and their spores from the Bohemian Carboniferous continental basins of the Czech Republic. Review of Palaeobotany and Palynology, 114: $57-81$.

Bek, J., Libertín, M. \& Drábková, J. 2009. Selaginella labutae sp. nov., a new compression herbaceous lycopsid and its spores from the Kladno-Rakovník Basin, Bolsovian of the Czech Republic. Review of Palaeobotany and Palynology, 155: 101-115.

Bertier, P., Swennen, R., Lagrou, D., Laenen, B. \& Kemps, R. 2008. Palaeo-climate controlled diagenesis of the Westphalian C \& D fluvial sandstones in the Campine basin (north-east Belgium). Sedimentology, 55: $1375-1417$.

Besly, B.M. \& Fielding, C.R. 1989. Palaeosols in Westphalian coalbearing and red-bed sequences, central and northern England. Palaeogeography, Palaeoclimatology, Palaeoecology, 70: 303-330.

Besly, B.M. \& Turner, P. 1983. Origin of red beds in a moist tropical climate (Etruria Formation, Upper Carboniferous, UK). In: Wilson, R.C.L. (Ed.), Residual deposits. Geological Society, London, Special Publications, 11: 131-147.

Bharadwaj, D.C. 1957a. The palynological investigations of the Saar coals. Paläeontographica Abteilung B, 101: 73-125.

Bharadwaj, D.C. 1957b. The spore flora of the Velener Schichten (Lower Westphalian D) in the Ruhr Measures. Paläeontographica Abteilung B, 102: $110-138$.

Bharadwaj, D.C. \& Kremp, G. 1955. Die Sporenführung der Velener Schichten des Ruhrkarbons. Geologisches Jahrbuch, 71: 51-68.

Bocheński, T. 1936. Über Sporophyllstände (Blüten) einiger Lepidophyten aus dem produktiven Karbon Polens. Annales de la Société géologique de Pologne, 12: 193-240.

Bode, H. 1928. Über eine merkwürdige Pteridophytenfruktifikation aus dem oberschlesischen Carbon. Jahrbuch der Preußischen Geologischen Landesanstalt, 49: 245-247.

Brack-Hanes, S.D. \& Thomas, B.A. 1983. A re-examination of Lepidostrobus Brongniart. Botanical Journal of the Linnean Society, 86: $125-133$.

British Geological Survey, 1972. 1: 63,360-scale geological special sheet 1, "Bristol District".
Chaloner, W.G. 1953a. On the megaspores of four species of Lepidostrobus. Annals of Botany, 17: 264-273.

Chaloner, W.G. 1953b. Species of Lepidostrobus containing unusual Spores. Geological Magazine, 90: 97-110.

Chaloner, W.G. 1953c. On the megaspores of Sigillaria. Annals and Magazine of Natural History, 5: 572-582.

Chaloner, W.G. 1954. Notes on the spores of two British Carboniferous lycopods. Annals and Magazine of Natural History, 12: 81-91.

Chaloner, W.G. 1956. On Sporangiostrobus langfordi sp. nov., a new fossil lycopod cone from Illinois. The American Midland Naturalist, 55: 437-444.

Clayton, G., Coquel, R., Doubinger, J. et al. 1977. Carboniferous miospores of Western Europe: Illustration and zonation. Mededelingen Rijks Geologische Dienst, 29: 1-71.

Cleal, C.J. 1986. Fossil plants of the Severn Coalfield and their biostratigraphical significance. Geological Magazine, 123: 553-568.

Cleal, C.J. 1987. Macrofloral biostratigraphy of the Newent Coalfield, Gloucestershire. Geological Journal, 22: 207-217.

Cleal, C.J. 1991. The age of the base of the Forest of Dean Coal Measures: Fact and fancy. Proceedings of the Geologists' Association, 102: 261-264.

Cleal, C.J. 1997. The palaeobotany of the upper Westphalian and Stephanian of southern Britain and its geological significance. Review of Palaeobotany and Palynology, 95: 227-253.

Cleal, C.J. 2007. The Westphalian-Stephanian macrofloral record from the South Wales Coalfield, UK. Geological Magazine, 144: 465-486.

Cleal, C.J. \& Thomas, B.A. 1996. British Upper Carboniferous stratigraphy, Geological Conservation Review Series. Chapman \& Hall, London, $356 \mathrm{pp}$.

Cottnam, C.F., Hemsley, A.R., Rossler, R., Collinson, M.E. \& Brain, A.P.R. 2000. Diversity of exine structure in Upper Carboniferous (Westphalian) selaginellalean megaspores. Review Palaeobotany and Palynology, 109: 33-44.

Couper, R.A. \& Grebe, H. 1961. A recommended terminology and descriptive method for spores. Compte Rendus, III, Reunion de la Commission Internationale de Microflore du Paleozoique, Krefeld, May 11-13, 1961, Report of Group No., 16, 1-15.

Crookall, R. 1925a. On the Fossil Flora of the Bristol and Somerset Coalfield I. Geological Magazine, 62: 145-180.

Crookall, R. 1925b. On the Fossil Flora of the Bristol and Somerset Coalfield II. Geological Magazine, 62: 385-408.

Dennis, R.L. \& Eggert, D.A. 1978. Parasporotheca, gen. nov., and its bearing on the interpretation of the morphology of permineralized Medullosan pollen organs. Botanical Gazette, 139: 117-139.

Dijkstra, S.J. 1946. Eine monographische Bearbeitung der Karbonischen Megasporen. Mededelingen van de Geologische Stichting, Nieuwe Serie, 3: $1-101$.

DiMichele, W.A. \& Phillips, T.L. 1994. Paleobotanical and palaeoecological constraints on models of peat formation in the Late Carboniferous of Euramerica. Palaeogeography, Palaeoclimatology, Palaeoecology, 106: 9-90.

DiMichele, W.A., Phillips, T.L. \& Pfefferkorn, H.W. 2006. Paleoecology of Late Paleozoic pteridosperms from tropical Euramerica. Journal of the Torrey Botanical Society, 133: 83-118.

Dimitrova, T., Cleal, C.J. \& Thomas, B.A. 2005. Palynology of late Westphalian-early Stephanian coal-bearing deposits in the eastern South Wales Coalfield. Geological Magazine, 142: 809-821.

Dix, E. 1934. The succession of floras in the Upper Carboniferous, with special reference to South Wales. Transactions of the Royal Society of Edinburgh, 57: 789-838.

Falcon-Lang, H.J., Benton, M.J., Braddy, S.J. \& Davies, S.J. 2006. The Pennsylvanian tropical biome reconstructed from the Joggins Formation of Nova Scotia, Canada. Journal of the Geological Society, London, 163: $561-576$.

Falcon-Lang, H.J., Pendleton, J.L. \& Wellman, C.H. 2011. Dryland plant communities in the Pennsylvanian (mid- to late Bolsovian) Winterbourne 
Formation of Bristol, southern Britain: Further evidence for taphonomic megabias. Review of Palaeobotany and Palynology, 166: 268-285.

Falcon-Lang, H.J., Cleal, C.J., Pendleton, J.L. \& Wellman, C.H. 2012. Permineralised plant assemblages from the Pennsylvanian (late Bolsovian-Asturian) Pennant Sandstone Formation of southern Britain: Systematics and palaeoecology. Review of Palaeobotany and Palynology, 173: 23-45.

Gastaldo, R.A., Pfefferkorn, H.W. \& DiMichele, W.A. 1995. Taphonomic and sedimentologic characterization of roof-shale floras. In: Lyons, P.C., Morey, E.D. \& Wagner, R.H. (Eds), Historical perspective of early twentieth century Carboniferous paleobotany in North America. Geological Society of America Memoir, 185: 341-351.

Glasspool, I.J., Hemsley, A.R., Scott, A.C. \& Golitsyn, A. 2000. Ultrastructure and affinity of Lower Carboniferous megaspores from the Moscow Basin, Russia. Review of Palaeobotany and Palynology, 109: $1-31$.

Glover, B.W., Powell, J.H. \& Waters, C.N. 1993. Etruria Formation (Westphalian C) palaeoenvironments and volcanicity on the southern margins of the Pennine Basin. South Staffordshire, England. Journal of the Geological Society, London, 150: 737-750.

Green, G.W. \& Welch, F.B.A. 1965. Geology of the Country Around Wells and Cheddar. Memoirs of the Geological Survey of the United Kingdom, HMSO, London, 225pp.

Hemsley, A.R. \& Scott, A.C. 1991. Ultrastructure and Relationships of Upper Carboniferous Spores from Thorpe-Brickworks, West Yorkshire, UK. Review of Palaeobotany and Palynology, 69: 337-351.

Horst, U. 1955. Die sporae dispersae des Namurs von Westoberschlesien und Mährisch-Ostrau. Paläeontographica Abteilung B, 98: 137-236.

Hower, J.C., Calder, J.H., Eble, C.F., Scott, A.C., Robertson, J.D. \& Blanchard, L.J. 2000. Metalliferous coals of the Westphalian A Joggins Formation, Cumberland Basin, Nova Scotia, Canada: Petrology, geochemistry and palynology. International Journal of Coal Geology, 42: 185-206.

Ibrahim, A.C. 1933. Sporenformen des Aegirhorizonts des Ruhr-Reviers. Konrad Triltsch, Würzburg, 47pp.

Jones, P.C. 1972. Quartzarenite and litharenite facies in the fluvial foreland deposits of the Trenchard Group (Westphalian), Forest of Dean, England. Sedimentary Geology, 8: 177-198.

Kellaway, G.A. \& Welch, F.B.A. 1993. Geology of the Bristol District: Memoir for 1:63,360 Geological Sheet (England and Wales). HMSO, London, $211 \mathrm{pp}$.

Leary, R.L. \& Mickle, J.E. 1989. Porostrobus nathorstii sp. nov.: A New Species of Lycopsid Cone from the Early Pennsylvanian of Illinois. American Journal of Botany, 76: 1638-1545.

Loboziak, S. 1971. The micro and megaspores of the western part of the northern Coal Basin of France. Paläeontographica Abteilung B, 132: $1-127$.

Loboziak, S. 1972. Contribution a la connaissance du Westphalien inferieur, les mégaspores de la bowette Sud á 248 de la fosse St. Mark de l'unite de production de Valenciennes des H.B.N.P.C. Annales de la Société Géologique du Nord, 92: 41-49.

Loboziak, S. \& Coquel, R. 1968. The micro and megaspores of the Faisceau de Dusouich in the Groupe de Lens, (H.B.N.P.C.). Annales de la Société Géologique du Nord, 88: 135-145.

Meyer-Berthaud, B. \& Galtier, G. 1986. Studies on a Lower Carboniferous flora from Kingswood near Pettycur, Scotland: II. Phacelotheca, a new synangiate fructification of pteridospermous affinities. Review of Palaeobotany and Palynology, 48: 181-198.

Millay, M.A. \& Taylor, T.N. 1974. Morphological studies of Paleozoic saccate pollen. Paläeontographica Abteilung B, 147: 75-99.

Millay, M.A. \& Taylor, T.N. 1976. Evolutionary trends in fossil gymnosperm pollen. Review of Palaeobotany and Palynology, 21: 65-91.

Millay, M.A., Eggert, D.A. \& Dennis, R.L. 1978. Morphology and ultrastructure of four Pennsylvanian prepollen types. Micropaleontology, 24: $303-315$.
Moore, L.R. \& Trueman, A.E. 1937. The Coal Measures of Bristol and Somerset. Quarterly Journal of the Geological Society of London, 93: 195-240.

Opluštil, S. \& Cleal, C.J. 2007. A comparative analysis of some Late Carboniferous basins of Variscan Europe. Geological Magazine, 3: 417-448.

Osborn, J.M. \& Taylor, T.N. 1994. Comparative ultrastructure of fossil gymnosperm pollen and its phylogenetic implications. In: Kurmann, M.H. \& Doyle, J.A. (Eds), Ultrastructure of Fossil Spores and Pollen: Its Bearing on Relationships Among Living and Fossil Groups. Royal Botanic Gardens, Kew, 99-121.

Pagnier, H.J.M. \& Van Tongeren, P.C.H. 1996. Upper Carboniferous of borehole 'De Lutte-6' and evaluation of the Tubbergen Formation in the eastern and southern parts of the Netherlands. Mededelingen Rijks Geologische Dienst, 55: 3-30.

Pendleton, J.L., Cleal, C.J., Falcon-Lang, H.J., Wagner, R.H. \& Wellman, C.H. 2012. Palaeobotany of the Pennsylvanian (mid-BolsovianCantabrian; Moscovian) Warwickshire Group of the Bristol Coalfield, U.K.: biostratigraphy and paleoecology. Review of Palaeobotany and Palynology, 179: 17-43.

Piérart, P. 1965. Megaspores of the French Stephanian. Mededelingen van de Geologische Stichting, 17: 27-30.

Pierce, T.J., Wray, D., Ratcliffe, K., Wright, D.K. \& Moscariello, A. 2005. Chemostratigraphy of the Upper Carboniferous Schooner Formation, southern North Sea. In: Collinson, J.D., Evans, D.J., Holliday, D.W. \& Jones, N.S. (Eds), Carboniferous Hydrocarbon Resources: The Southern North Sea and Surrounding Onshore Areas. Yorkshire Geological Society Occasional Publication Series, 7: 147-164.

Pigg, K.B. 1983. The morphology and reproductive biology of the sigillarian cone. Mazocarpon. Botanical Gazette, 144: 600-613.

Pigg, K.B. \& Rothwell, G.W. 1983. Chaloneria gen. nov. heterosporous lycophytes from the Pennsylvanian of North America. Botanical Gazette, 144: 132-147.

Potonié, R. 1967. Versuch der Einordnung der fossilen Sporae dispersae in das phylogenetische System der Pflanzenfamilien. Pt 1. Thallophyta bis Gnetales. Forschungsberichte des Landes Nordrhein-Westfalen, 1761: $1-310$.

Potonié, R. \& Kremp, G. 1954. Die Gattungen der paläozoischen Sporae dispersae und ihre Stratigraphie. Geologisches Jahrbuch, 69: 111-194.

Potonié, R. \& Kremp, G. 1955. Die sporae dispersae des Ruhrkarbons, ihre Morphographie und Stratigraphie mit Ausblicken auf Arten anderer Gebeite und Zeitabschnitte: Teil I. Paläeontographica Abteilung B, 98: $1-136$.

Potonié, R. \& Kremp, G. 1956. Die sporae dispersae des Ruhrkarbons, ihre Morphographie und Stratigraphie mit Ausblicken auf Arten anderer Gebeite und Zeitabschnitte: Teil II. Paläeontographica Abteilung B, 99: 85-191.

Pringle, J. 1921. On a Boring for Coal at Yate, Gloucestershire. Summary of Progress of the Geological Survey of Great Britain for 1920, 92-95.

Punt, W., Hoen, P.P., Blackmore, S., Nilsson, S. \& Le Thomas, A. 2007. Glossary of pollen and spore terminology. Review of Palaeobotany and Palynology, 143: 1-81.

Ravn, R.L. 1986. Palynostratigraphy of the Lower and Middle Pennsylvanian coals of Iowa. Iowa Geological Survey Technical Paper, 7: 1-245.

Rayner, R.J. 1986. Azaniodendron a new genus of lycopod from South Africa. Review of Palaeobotany and Palynology, 47: 129-143.

Rößler, R. \& Buschmann, B. 1994. Some herbaceous lycopods from the Westphalian D of Germany. Review of Palaeobotany Palynology, 80: 259-275.

Rothwell, G.W. 1972. Evidence of pollen tubes in Paleozoic pteridosperms. Science, 175: 772-774.

Schopf, J. 1938. Spores from the Herrin (no. 6) Coal Bed Illinois. Report of Investigations of the Illinois Geological Survey, 50: 1-73.

Schwendemann, A.B., Wang, G., Mertz, M.L., McWilliams, R.T., Thatcher, S.L. \& Osborn, J.M. 2007. Aerodynamics of saccate pollen 
and its implications for wind pollination. American Journal of Botany, 94: $1371-1381$.

Scott, A.C. \& Hemsley, A.R. 1996. Paleozoic megaspores. In: Jansonius, J. \& McGregor, D.C. (Eds), Palynology: Principles and Applications. American Association of Stratigraphic Palynologists Foundation, College Station, Texas, 629-639.

Scott, A.C. \& King, G.R. 1981. Megaspores and coal facies: An example from the Westphalian A of Leicestershire, England. Review of Palaeobotany and Palynology, 34: 107-113.

Smith, A.H.V. 1957. The Sequence of Microspore Assemblages Associated with the Occurrence of Crassidurite in Coal Coals of Yorkshire. Geological Magazine, 94: 345-363.

Smith, A.H.V. \& Butterworth, M.A. 1967. Miospores in the coal seams of the Carboniferous of Great Britain. Special Papers in Palaeontology, 1: $1-324$

Soyez, C. 1967. Quantitative study of the 'Tuberculatisporites' in the mines of the Midi (Group of Douai of the H.B.N.P.C.). Annales de la Société Géologique du Nord, 87: 163-170.

Spinner, E.G. 1965. Westphalian D megaspores from the Forest of Dean Coalfield, England. Palaeontology, 8: 82-106.

Spinner, E.G. 1966. Palynological evidence on the age of the Carboniferous beds of Woodbury Hill, near Abberley, Worcestershire. Proceedings of the Yorkshire Geological Society, 35: 507-522.

Stidd, B.M. 1978. An anatomically preserved Potoniéa with in situ spores from the Pennsylvanian of Illinois. America Journal of Botany, 65: 677-683.

Stubblefield, C.J. \& Trotter, F.M. 1957. Divisions of the Coal Measures on Geological Survey maps of England and Wales. Bulletin of the Geological Survey of Great Britain, 13: 1-5.

Taylor, T.N. 1982. Ultrastructural studies of Paleozoic seed fern pollen: Sporoderm development. Review of Palaeobotany and Palynology, 37 29-53.

Taylor, T.N., Taylor, E.L. \& Krings, M. 2009. Paleobotany: The Biology and Evolution of Plants (2nd edn). Elsevier, Amsterdam, 1230pp.

Turner, N. \& Spinner, E. 1990. Palynological evidence for the age of the Coal Measures of the Titterstone Clee Coalfield, Shropshire, England Proceedings of the Yorkshire Geological Society, 48: 81-89.
Wagner, R.H. 1966. Palaeobotanical dating of Upper Carboniferous folding phases in NW Spain. Memorias del Instituto Geologico y Minero de España, 66: 1-169.

Wagner, R.H. \& Spinner, E. 1972. The stratigraphic implications of the Westphalian D macro- and microflora of the forest of Dean Coalfield (Gloucestershire), England. International Geological Congress, 7: 428-437.

Waters, C.N. \& Davies, S.J. 2006. Carboniferous extensional basins, advancing deltas and coal swamps. In: Brenchley, P.J. \& Rawson, P.F. (Eds), The Geology of England and Wales (2nd edn). Geological Society, London, 173-223.

Waters, C.N., Waters, R.A., Barclay, W.J. \& Davies, J.R. 2009. A lithostratigraphical framework for the Carboniferous successions of southern Great Britain (Onshore). British Geological Survey, Research Report RR/09/01, 184pp.

Waters, C.N., Waters, R.A., Jones, N.S., Cleal, C.J. \& Davies, J.R. 2011. Bristol, Mendips and Forest of Dean. In: Waters, C.N., Somerville, I.D. et al. (Eds), A Revised Correlation of Carboniferous Rocks in the British Isles. Geological Society, London, Special Reports, 26: 37-43.

Wellman, C.H. 2009. Ultrastructure of dispersed and in situ specimens of the Devonian spore Rhabdosporites langii (Eisenack) Richardson 1960: Evidence for the evolutionary relationships of Progymnosperms. Palaeontology, 52: 139-167.

Winslow, M.R. 1959. Upper Mississippian and Pennsylvanian megaspores and other plant microfossils from Illinois. Illinois State Geological Survey Bullitin, 86: 1-135.

Zeiller, R. 1886. Bassin Houiller de Valenciennes, Description de la Flore Fossile, Atlas Études des Gîtes Mineraux de la France. Maison Quantin, Paris, 731pp.

Zeiller, R. 1906. Bassin houiller et permien de Blanzy et du Creusot. Flore fossile. Atlas Études des Gîtes Minéraux de la France. Imprimérie Nationale, Paris, 261pp.

Zerndt, J. 1934. Les megaspores du bassin houiller Polonais; premier partie. Académie Polonaise, Science Bulletin International, Travaux Géologiques, 1: 1-55. 